\title{
Perspectives for Glyco-Engineering of Recombinant Biopharmaceuticals from Microalgae
}

\author{
Lorenzo Barolo $^{1, *}$, Raffaela M. Abbriano ${ }^{1}{ }^{\mathbb{B}}$, Audrey S. Commault ${ }^{1}{ }^{\circledR}$, Jestin George ${ }^{1}$, \\ Tim Kahlke ${ }^{1}$, Michele Fabris ${ }^{1,2}{ }^{-}$, Matthew P. Padula ${ }^{3}{ }^{\complement}$, Angelo Lopez ${ }^{4} \mathbb{D}$, Peter J. Ralph ${ }^{1}$ and \\ Mathieu Pernice ${ }^{1, *(D)}$ \\ 1 Climate Change Cluster, University of Technology Sydney, Broadway Campus, Ultimo NSW 2007, Sydney, \\ Australia; Raffaela.AbbrianoBurke@uts.edu.au (R.M.A.); Audrey.Commault@uts.edu.au (A.S.C.); \\ Jestin.George@student.uts.edu.au (J.G.); Tim.Kahlke@uts.edu.au (T.K.); Michele.Fabris@uts.edu.au (M.F.); \\ Peter.Ralph@uts.edu.au (P.J.R.) \\ 2 CSIRO Synthetic Biology Future Science Platform, Brisbane, QLD 4001, Australia \\ 3 School of Life Sciences and Proteomics Core Facility, Faculty of Science, University of Technology Sydney, \\ Ultimo NSW 2007, Sydney, Australia; Matthew.Padula@uts.edu.au \\ 4 Department of Chemistry, University of York, York, YO10 5DD, UK; al1510@york.ac.uk \\ * Correspondence: lorenzo.barolo@student.uts.edu.au (L.B.); Mathieu.pernice@uts.edu.au (M.P.)
}

Received: 12 February 2020; Accepted: 28 February 2020; Published: 5 March 2020

\begin{abstract}
Microalgae exhibit great potential for recombinant therapeutic protein production, due to lower production costs, immunity to human pathogens, and advanced genetic toolkits. However, a fundamental aspect to consider for recombinant biopharmaceutical production is the presence of correct post-translational modifications. Multiple recent studies focusing on glycosylation in microalgae have revealed unique species-specific patterns absent in humans. Glycosylation is particularly important for protein function and is directly responsible for recombinant biopharmaceutical immunogenicity. Therefore, it is necessary to fully characterise this key feature in microalgae before these organisms can be established as industrially relevant microbial biofactories. Here, we review the work done to date on production of recombinant biopharmaceuticals in microalgae, experimental and computational evidence for $\mathrm{N}$ - and $\mathrm{O}$-glycosylation in diverse microalgal groups, established approaches for glyco-engineering, and perspectives for their application in microalgal systems. The insights from this review may be applied to future glyco-engineering attempts to humanize recombinant therapeutic proteins and to potentially obtain cheaper, fully functional biopharmaceuticals from microalgae.
\end{abstract}

Keywords: algae; glycosylation; recombinant protein

\section{Introduction}

Biopharmaceuticals are biological macromolecules that exhibit therapeutic actions in humans. This group of compounds includes essential molecules such as antibodies, hormones, and vaccines [1]. More than $60 \%$ of commercialized biopharmaceuticals are recombinant proteins [2], which are produced in genetically engineered host cells defined as biofactories [3]. Biofactories can include a broad spectrum of host organisms spanning from prokaryotic to eukaryotic cells and support a US\$140 billion biopharmaceuticals market [4].

Currently, the host cell systems Escherichia coli (bacteria), Saccharomyces cerevisiae and Pichia pastoris (yeast), and Chinese hamster ovary $(\mathrm{CHO})$ cells (mammalian) dominate the production of biopharmaceuticals, with the mammalian $\mathrm{CHO}$ cells covering $>50 \%$ of the market [5]. However, these four cell systems have several disadvantages, including species-specific issues related to the nature of 
each biofactory. E. coli often incurs translational errors, accumulates inclusion bodies, and completely lacks the eukaryotic organelles and machinery necessary to produce fundamental post-translational modifications (PTMs) [6]. Challenges with using yeasts include inadequate protein secretion and incorrect protein PTMs $[7,8]$. Biopharmaceutical production with $\mathrm{CHO}$ cells is expensive because of the complex culturing requirements associated, difficult to scale, and susceptible to contamination with human viruses and prions $[9,10]$. These complications have prompted efforts to optimize these systems as well as identify more suitable host cell lines. In this context, microalgae have emerged as attractive novel expression systems for biopharmaceutical production.

Chlamydomonas reinhardtii (Chlorophyceae) has historically been the model microalgal species for biotechnological innovations [11], due to its advantageous biological features [12,13]. However, other species are increasingly being evaluated for their capacity to produce recombinant proteins. Microalgae including Chlorella sp. (Trebouxiophyceae) [14,15], Dunaliella salina (Chlorophyceae) [16], Nannochloropsis oculata (Eustigmatophyceae) $[17,18]$ and the diatom Phaeodactylum tricornutum (Bacillariophyceae) [19] have been reported to successfully express biopharmaceuticals.

A major challenge with producing biopharmaceuticals in non-human cells is obtaining correct post-translational modifications (PTMs) of the recombinant protein. Since each host cell system possesses its own unique protein processing machinery at a translational and post-translational level, the same recombinant protein produced in different cell systems can display different and unique PTMs [20-24]. PTMs such as phosphorylation, acetylation, methionine oxidation, asparagine and glutamine deamination, proteolysis, disulphide bond formation, and glycosylation all play a significant role in stability, functionality, and activity of proteins [25]. Among these, glycosylation is a major PTM that is found on more than $50 \%$ of human proteins [26]. In biopharmaceutical production, over $40 \%$ of approved therapeutic proteins are glycosylated, highlighting the importance of understanding and controlling the glycosylation mechanism of non-human expression systems [27,28].

The cellular mechanisms that determine protein glycosylation patterns are complex and vary among different eukaryotic species [29]. Given the significant influence of glycosylation on yield, efficacy, pharmacokinetics, and immunogenicity of recombinant therapeutic proteins, it is essential to choose the right host expression system to successfully produce a functional biopharmaceutical [30]. Additionally, sub-optimal glycosylation of recombinant proteins can be overcome using glyco-engineering strategies [31]. Glyco-engineered biopharmaceuticals will present "humanized" glycans that will not be immunogenic to humans [4].

In this review, we provide a brief overview of various host systems, with a focus on the advantages and disadvantages of microalgae as biofactories for the production of recombinant therapeutic proteins. We also discuss strategies to overcome the challenges, with a focus on microalgae glycosylation status and its comparison to human glycosylation. Lastly, we assess the prospect of applying glyco-engineering techniques to optimize recombinant biopharmaceutical production in microalgal host systems.

\section{Production of Biopharmaceuticals in Alternative Hosts}

Due to improvements in genetic engineering technologies and recombinant protein expression, the repertoire of biopharmaceuticals produced in biofactories is expanding. Increased capability to replicate the functional characteristics of larger, more complex proteins [32] has broadened the range of potential biopharmaceutical applications, including treatments for cancer and autoimmune diseases [33]. This is particularly evident for antibodies [32], which have been replicated in various forms including single-chain fragment variables (scFvs) [34] and antigen-binding fragments (Fabs) [35], amongst others. The choice of biofactory is primarily based on the type of biopharmaceutical (e.g., functional multi-domain mammalian proteins cannot be produced in bacteria as they require specific PTMs), but other factors such as production costs, yields, time to market, and the safety of the patient are also considered when selecting an expression host. The recent production of a biopharmaceutical used as a treatment for the Ebola virus in Western Africa has proven that plants 
(in this case Nicotiana benthamiana) can be a powerful alternative to common expression systems, especially for rapid and low-cost production of antibodies using technologies that are relatively simple to implement in developing countries [36-38]. Among the multitude of alternative expression hosts, photosynthetic systems have emerged with high potential to offer a rapid and cost-effective alternative to traditional hosts. The previously described traditional biofactories are all heterotrophic systems and rely on the addition of organic carbon sources to the culture media, whilst photosynthetic organisms can generate biomass using $\mathrm{CO}_{2}$ and light, lowering not only carbon footprint but also media complexity and costs associated with recombinant protein production. In recent decades, plant cells and microalgal organisms have been analysed for their promising role as photosynthetic host systems, with the latter being the focus of this review.

\section{Microalgal Biofactories}

Microalgae are unicellular photosynthetic organisms found in both terrestrial and aquatic environments [39]. The potential of microalgae to produce natural products with commercial value, ranging from food additives and health supplements to biofuels and cosmetics, has currently become widely recognized [40]. Recent advances in genetic engineering have enabled expression of many recombinant biopharmaceuticals in microalgal hosts (Table 1).

Microalgal biofactories possess many unique advantages. Like plants, microalgae can be cultivated in large areas and require a lower up-front investment compared to bacterial or mammalian cell systems [41]. Additionally, microalgae do not harbor human pathogens and some species are generally recognized as safe (GRAS) [12]. They are easy to cultivate in bioreactors, and thus are less prone to airborne contamination issues [12]. Moreover, microalgae have higher growth rates and less complex media requirements compared to plants, and therefore potentially lower production costs [10-12]. Furthermore, microalgae are unicellular organisms that lack functional parts such as roots and leaves, making recombinant biopharmaceuticals production more uniform within the same batch and diminishing the energy and resources needed to generate additional biomass [12].

One of the better characterized and widely exploited microalgae for recombinant protein production is the biflagellate chlorophyte C. reinhardtii [42]. This species has become the model algae to explore and understand the biological processes occurring within the green microalgal lineage due to an advanced genetic toolkit and the availability of fully sequenced nuclear and organellar genomes [12]. C. reinhardtii is now the most comprehensive microalgal platform for expression of recombinant proteins with promising industry applications in the bioenergy, biopharmaceutical, biomaterial, and nutraceutical sectors [11,43]. A recent toxicology study demonstrated that C. reinhardtii biomass is safe for human consumption [44], and although C. reinhardtii-derived products are not yet commercially available, extensive research on large-scale cultivation is bringing it closer to reality [45].

Recombinant protein production in C. reinhardtii has been achieved by engineering both the chloroplast and nuclear genomes. In the chloroplast, the level of transgenic expression can reach $20 \%$ of total soluble protein (TSP) [10]. However, recombinant proteins expressed in the chloroplast are retained inside the plastid and cannot be secreted [46]. Therefore, recombinant proteins expressed in the chloroplast are unable to pass through the secretion route via the endoplasmic reticulum and the Golgi apparatus, and cannot be subjected to fundamental PTMs such as glycosylation [12,46]. Hence, chloroplast expression is only suitable for non-glycosylated proteins. Recombinant proteins expressed from the nucleus, on the other hand, can be targeted to the secretion route by adding specific signal peptides to the recombinant amino acid sequence, resulting in secretion and glycosylation of the recombinant protein [10]. Unfortunately, nuclear expression results in very low yields, due to random integration, low transformation efficiency, and gene silencing mechanisms [46,47]. 
Table 1. Twenty years of recombinant biopharmaceutical production in microalgae.

\begin{tabular}{|c|c|c|c|}
\hline Organism & Organelle & Protein & Reference \\
\hline C. reinhardtii & Chloroplast & $\begin{array}{l}\text { E7 of HPV-16 } \\
\text { D2-CTB } \\
\alpha \text {-galactosidase } \\
\text { Phytase } \\
\text { Xylanase } \\
\text { Pfs25 } \\
\text { Pfs28 } \\
\text { Pfs25-CTB } \\
\text { E2 } \\
\text { Pfs48/45 } \\
\text { M-SAA } \\
\text { Anti-HSV glycoprotein D Isc } \\
\text { 12FN3 } \\
\text { Erythropoietin } \\
\text { HMGB1 } \\
\text { Interferon } \beta \\
\text { Proinsulin } \\
\text { SAA-10FN3 } \\
\text { VEGF } \\
\text { Allophycocyanin } \\
\text { VP1-CTB } \\
\text { V28 } \\
\text { Anti-PA 83 anthrax IgG1 } \\
\text { Anti-CD22-gelonin sc } \\
\text { Anti-CD22-ETA sc } \\
\text { GAD65 } \\
\text { TRAIL } \\
\text { Phytase (AppA) } \\
\text { Metallothionein-2 }\end{array}$ & $\begin{array}{l}{[48]} \\
{[49]} \\
{[50]} \\
{[50]} \\
{[50]} \\
{[51]} \\
{[51]} \\
{[52]} \\
{[53]} \\
{[54]} \\
{[55]} \\
{[56]} \\
{[57]} \\
{[57]} \\
{[57]} \\
{[57]} \\
{[57]} \\
{[57]} \\
{[57]} \\
{[58]} \\
{[59]} \\
{[60]} \\
{[61]} \\
{[62]} \\
{[63]} \\
{[64]} \\
{[65]} \\
{[66]} \\
{[67]}\end{array}$ \\
\hline C. reinhardtii & Nucleus & $\begin{array}{l}\text { Human Epidermal Growth Factor } \\
\text { VEGF-165 } \\
\text { GBSS-AMA1 } \\
\text { GBSS-MSP1 } \\
\text { Erythropoietin } \\
\text { Sep-15 } \\
\text { Lolium Perenme IBP } \\
\beta-1,4 \text {-endoxylanase }\end{array}$ & $\begin{array}{l}{[68]} \\
{[69]} \\
{[70]} \\
{[70]} \\
{[42]} \\
{[71]} \\
{[72]} \\
{[73]}\end{array}$ \\
\hline $\begin{array}{l}\text { C. vulgaris } \\
\text { C. sorokiniana }\end{array}$ & Nucleus & Human growth hormone & [14] \\
\hline C. ellipsoidea & Nucleus & $\begin{array}{l}\text { mNP-1 } \\
\text { NP-1 } \\
\text { Flounder growth hormone }\end{array}$ & $\begin{array}{l}{[15]} \\
{[74]} \\
{[75]}\end{array}$ \\
\hline D. salina & Chloroplast & $\begin{array}{l}\alpha \text {-galactosidase } \\
\text { Phytase } \\
\text { Xylanase }\end{array}$ & $\begin{array}{l}{[50]} \\
{[50]} \\
{[50]}\end{array}$ \\
\hline D. salina & Nucleus & $\begin{array}{l}\text { V28 } \\
\text { HBsAg }\end{array}$ & $\begin{array}{l}{[76]} \\
{[16]}\end{array}$ \\
\hline P. tricornutum & Nucleus & $\begin{array}{l}\text { Anti-Hepatitis B IgG } \\
\text { Anti-MARV NP IgG }\end{array}$ & $\begin{array}{l}{[19]} \\
{[77]}\end{array}$ \\
\hline N. oculata & $\begin{array}{l}\text { Nucleus } \\
\text { Nucleus }\end{array}$ & $\begin{array}{l}\text { Bovine lactoferricin (LFB) } \\
\text { Flounder growth hormone }\end{array}$ & $\begin{array}{l}{[18]} \\
{[17]}\end{array}$ \\
\hline
\end{tabular}


As increasing knowledge and genetic tools become available, other microalgae species have been exploited for recombinant protein production, including monoclonal antibodies, hormones, and enzymes. Several species, including Chlorella vulgaris, Chlorella sorokiniana, Chlorella ellipsoidea, D. salina, $N$. oculata, and the diatom P. tricornutum have been successfully used to express biopharmaceuticals (Table 1). In particular, P. tricornutum has gained noticeable importance due to the ability to secrete fully functional IgG antibodies [19]. An overview of the recombinant biopharmaceuticals produced in microalgae over the last two decades is presented in Table 1.

Few recombinant biopharmaceuticals produced in alternative host systems have successfully passed clinical trials and reached commercialization status $[2,78]$. One is ELELYSO ${ }^{\circledR}$, a recombinant glucocerebrosidase produced in carrot cells and approved for Gaucher's disease treatment by FDA in $2012[2,79]$. The second one is ZMapp, an antibody cocktail administered during the Ebola virus outbreak in Western Africa [36-38]. One component of ZMapp (cZMAb) was produced in N. benthamiana [37,38]. Recently, two new antibody therapies outperformed ZMapp, leading to a different approved therapy for the Ebola virus [80]. Microalgal biopharmaceuticals are still absent from the market, mainly due to the low yields of recombinant proteins obtained from these biofactories [46,47].

\section{Post-Translational Modifications and Glycosylation}

Post-translational modifications (PTMs) are chemical modifications of a protein during or after its synthesis within the cell. Amino acids, the building blocks that define the physio-chemical structure and functionality of a protein, can be altered by more than 250 different PTMs [81]. The repertoire of PTMs is very complex, considering that 15 out of the 20 common amino acids can be modified [82]. More than $5 \%$ of the total human genome encodes for enzymes involved in PTMs, including those involved in phosphorylation (kinases and phosphatases), acetylation (acetylases and deacetylases), and glycosylation (glycosyltransferases) [27]. Protein PTMs, together with alternative RNA splicing and translation, enhance molecular diversification of gene products and participate in a complex system to regulate the physiology of eukaryotic cells $[27,83]$.

PTMs such as phosphorylation, glycosylation, and nitration are involved in important cellular processes [84]. For example, phosphorylation can operate as switches to modulate specific catalytic activities of the protein [85]. Another function of PTMs is to mark proteins for degradation by ubiquitination [85]. PTMs can also act in response to external stimuli, for example, when a cell is subjected to biological stress it can activate proteins with specific PTMs to counteract the stress [86]. Of the many PTMs relevant to biopharmaceutical production, glycosylation plays a major role. In fact, glycosylation is found on more than $50 \%$ of human proteins [26], and on more than $40 \%$ of approved recombinant biopharmaceuticals, highlighting the importance to understand and control the glycosylation mechanism of non-human expression systems [27,28].

Glycosylation refers to a covalent bond between a polysaccharide chain and an amino acid, formed during translation of the protein. The two most frequent types of glycosylation are $N$-linked and $\mathrm{O}$-linked glycosylation. $\mathrm{N}$-linked glycosylation is characterized by the formation of a covalent bond between the glycan and the amidic group of an asparagine (Asn) residue. O-linked glycosylated proteins have the glycan linked to the hydroxyl component of a serine (Ser) or a threonine (Thr) residue. Glycosylated proteins and glycan structures strongly regulate fundamental biological processes within the cell, such as cell adhesion, self/nonself recognition, molecular trafficking and clearance, receptor activation, and endocytosis [87].

Glycosylation significantly enhances yield, folding, efficacy, and pharmacokinetics of recombinant biopharmaceuticals [30]. During recombinant protein production, non-human host organisms can attach glycan residues (monosaccharides) that would be absent on the human endogenous protein, potentially resulting in lower yields, incorrect folding, and inefficacy of the biopharmaceutical [10]. For example, glycosylation plays a fundamental role in activity of antibody-based therapeutics [88]. In fact, antibodies can target and kill hostile cells by antibody-dependent cellular cytotoxicity (ADCC) or complement-dependent cytotoxicity (CDC) mechanisms, and both ADCC and CDC are directly related 
to glycosylation presence and status of the antibody [89-91]. Therefore, an antibody carrying incorrect glycosylation might show diminished activity. Moreover, correct glycosylation and proper folding also affect immunogenicity and antigenicity of recombinant biopharmaceuticals. Immunogenicity is the capability of a molecule to trigger an immune response in the patient, whilst antigenicity is the ability of a molecule to bind immune system products. Therefore, an antigen is not necessarily an immunogen, whilst an immunogen is inevitably an antigen. Immunogenic biopharmaceuticals can trigger an immune response in the patient resulting in accelerating clearance during therapy or, in some rare cases, life threatening complications [92]. Glycans can trigger an immunogenic reaction either indirectly or directly. Glycosylation can have an indirect effect on immunogenicity by influencing therapeutic proteins folding, solubility and structural stability [93]. In fact, incorrect or no glycosylation can alter the secondary/tertiary structure and/or prompt aggregation of therapeutic proteins, factors breaking the immune tolerance of the patient. Moreover, specific non-human residues can be directly recognised as exogenous by the patient immune system and trigger an immunogenic response [94]. At least four non-human glycans have been identified as being able to induce an immune response in humans. These residues are: $\alpha$-Gal, Neu5Gc, $\beta(1,2)$-xylose and $\alpha(1,3)$-fucose [93]. The $\alpha$-Gal and Neu5Gc residues are present in therapeutics produced in mammalian cells such as $\mathrm{CHO}$ cells, while $\beta(1,2)$-xylose and $\alpha(1,3)$-fucose are present in plant and microalgal-produced glycoproteins [93]. Given the crucial role of glycosylation in folding, activity, and immunogenicity of biopharmaceuticals, it is essential to understand the glycosylation capabilities of a chosen biofactory to produce properly folded, effective, and safe recombinant therapeutics.

\subsection{N-Glycosylation}

$\mathrm{N}$-glycosylation requires a strict consensus sequence, where the amino acid sequence must be Asn-Xxx-Ser/Thr [95], where Xxx can be any amino acid other than proline (Pro). Further studies expanded this sequence to a less frequent, but still relevant, Asn-Xxx-Cysteine (Cys), Asn-Xxx-Valine (Val), and Asn-Glycine (Gly) [96].

$\mathrm{N}$-glycosylation begins in the endoplasmic reticulum (ER), where a biosynthetic precursor, a dolichol-PP-linked oligosaccharide (comprised of 3 glucose (Glu), 9 mannose (Man) and $2 \mathrm{~N}$-acetylglucosamine (GlcNAc) residues) is transferred to Asn residues in nascent polypeptide chains (Figure 1). The glycan is then subjected to further enzymatic maturation as part of a quality control by chaperones (calnexin and calreticulin). The newly formed glycoprotein is then transferred to the Golgi apparatus and further modified by many different glycosyltransferases, until reaching final maturation. $\mathrm{N}$-glycans across different eukaryotic organisms present a common structure called the "pentasaccharide core" (2 N-acetylglucosamine (GlcNAc) and 3 mannose (Man) residues) [10,97] (Figure 1). The rest of the residues will attach onto the final two Man of the pentasaccharide core, thus creating two polysaccharide antennae. However, unlike the well-conserved pentasaccharide core, the rest of the $N$-glycan structure vastly varies amongst eukaryotes. In fact, the final maturation of the glycan in the Golgi apparatus by different glycosyltransferases is a species-specific mechanism and is the source of different glycosylation patterns among eukaryotic organisms [98,99] (Figure 1).

In humans, depending on how the two terminal Man residues are elongated, three different specific $N$-glycans structures are possible: (i) "oligo-mannose" glycans containing only mannose residues, (ii) "hybrid" glycans with mannose residues on one antenna and mixed monosaccharides on the second antenna, and (iii) "complex" glycans with mixed monosaccharides on both antennae [100]. As a glycoprotein enters the Golgi, it is N-linked to 8/9 Man and 2 GlcNAc. This chain is reduced to 5 Man and 2 GlcNAc by an enzyme called $\alpha$-mannosidase I ( $\alpha$-Man I) (Figure 1). Then, the $N$-acetylglucosaminyltransferase I (GnT I) plays a key role by transferring one $N$-acetylglucosamine residue on the $\alpha(1,3)$-mannose arm of the 5 Man and 2 GlcNAc $N$-linked protein. This structure (1 GlcNAc, $5 \mathrm{Man}$ and $2 \mathrm{GlcNAc}$ ) is the starting point for both "hybrid" and "complex" structures (Figure 1). From that point on, many different glycosyltransferases will build the complete pattern of the $\mathrm{N}$-glycoprotein [101]. 


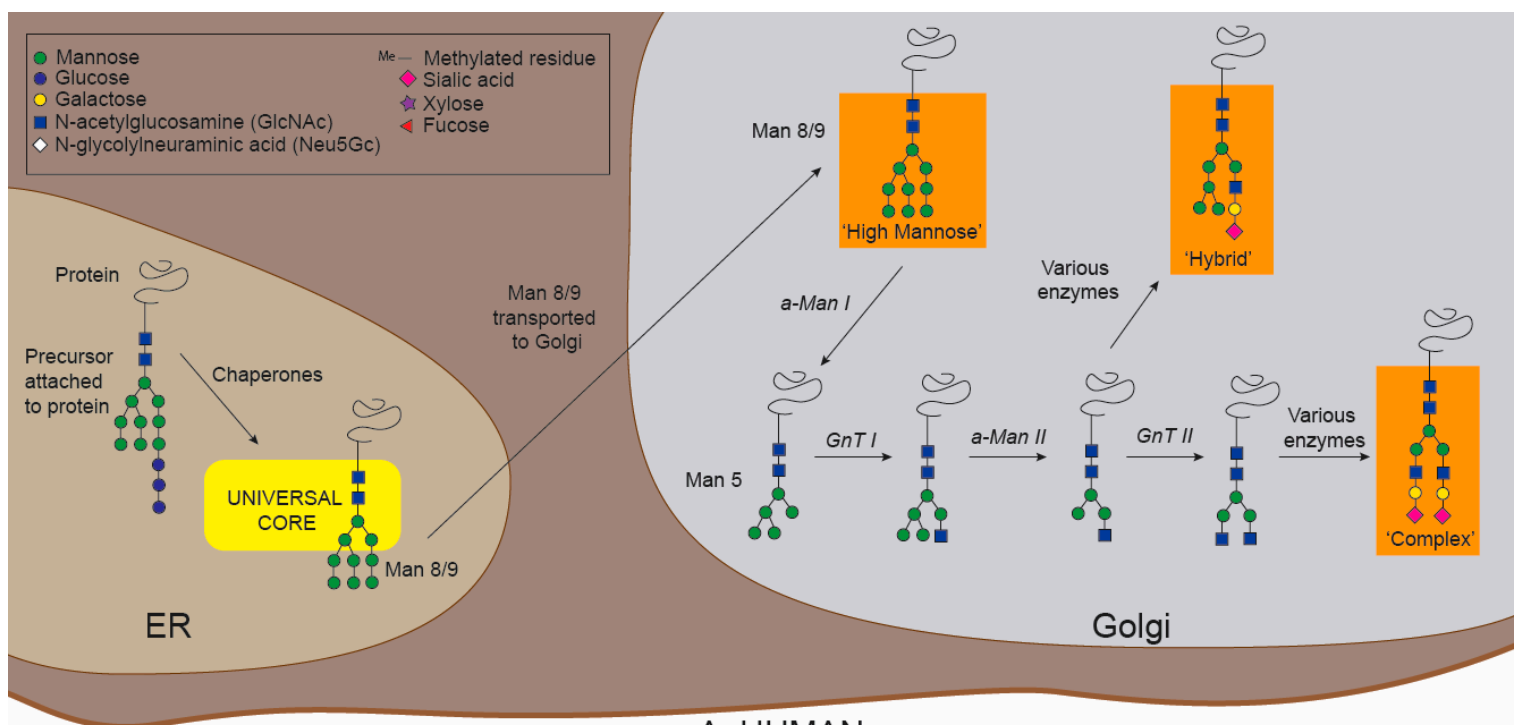

A. HUMAN

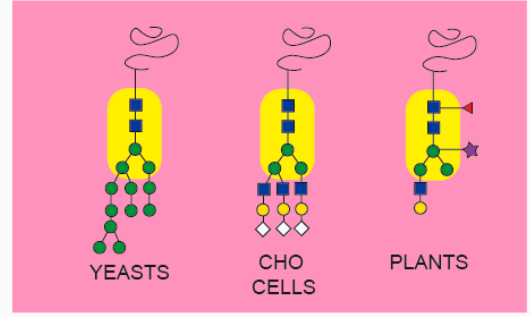

B. ESTABLISHED BIOFACTORIES

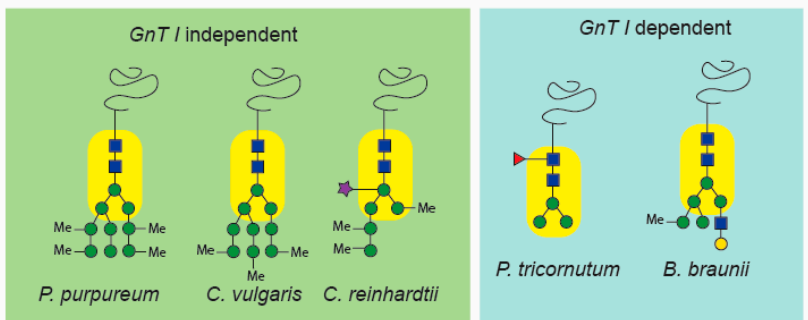

C. MICROALGAE

Figure 1. A schematic of $N$-glycosylation patterns found in (A) humans, (B) established biofactories including yeasts, plants, $\mathrm{CHO}$ cells, and (C) specific $\mathrm{N}$-glycosylation patterns in microalgae. Glycans shown for (A) humans and (B) established biofactories are only illustrative and do not represent the totality of possible glycoforms obtained from these organisms. Differences in specificity of yeast, $\mathrm{CHO}$, plant, and microalgal Golgi glycosyltransferases and glycosidases lead to variations in the final glycosylation profiles compared to humans. Consequently, glycans $N$-linked to recombinant proteins produced in these biofactories differ from native human proteins, necessitating glycan engineering to produce efficient and safe biopharmaceuticals in these alternative host systems. Green circle = Mannose. Blue circle $=$ Glucose. Yellow circle $=$ Galactose. Blue square $=$ GlcNAc. White diamond $=$ Neu5Gc. $\mathrm{Me}=$ Methylated residue. Fuchsia diamond $=$ Sialic acid. Purple star $=$ Xylose. Red triangle $=$ Fucose . $\alpha$-Man I $=\alpha$-mannosidase I. GnT I $=N$-acetylglucosaminyltransferase I. $\alpha$-Man II $=\alpha$-mannosidase II. GnT II = N-acetylglucosaminyltransferase II.

Bacteria, yeast, $\mathrm{CHO}$, and plant glycoproteins possess species-specific $N$-glycans that differ from human N-glycans (Figure 1B). Glycosylation and PTMs in general are challenging issues for E. coli, as most prokaryotes lack the eukaryotic PTM machinery to perform glycosylation [6]. It is possible to transfer the basic prokaryotic glycosylation machinery of another bacteria (Campylobacter jejuni) into E. coli to obtain glycosylated recombinant biopharmaceuticals [102]. However, prokaryotic glycans do not show similarities with human glycosylation patterns, resulting in immunogenic biopharmaceuticals [102,103]. Yeast glycans present an excess of mannose residues assembled together in "hyper-mannosidic" structures [104], which greatly differ from the human patterns [4,105]. Although CHO cells possess human-like glycosylation machinery, some discrepancies still persist [4]. For example, the absence of fundamental human residues like $\alpha(2,6)$-sialic acid and $\alpha(1,4)$-fucose, and the production of undesired non-human residues such as $N$-glycolylneuraminic acid (Neu5Gc) and galactose- $\alpha(1,3)$-galactose ( $\alpha$-Gal), can result in the production of potentially immunogenic recombinant 
biopharmaceuticals $[4,33]$. Similarly, plant cells produce glycans containing immunogenic residues such as $\beta(1,2)$-xylose and core $\alpha(1,3)$-fucose [106].

Compared to other systems, very little is known about $N$-glycosylation in microalgae. The combination of genomic annotation and experimental evidence has revealed some details about $\mathrm{N}$-glycans in some species; however, more information is needed. Analysis of five different microalgal species [94,107-111] showed two different glycosylation pathways based on presence or absence of the GnT I enzyme. The green microalgae C. reinhardtii and C. vulgaris, and the red microalga Porphyridium purpureum lack GnT I, which has been validated experimentally $[94,107,108,111]$. Thus, the $N$-glycosylation pathway in these species is defined as GnT I-independent. In this pathway, the 5 Man and 2 GlcNAc $N$-linked protein is subjected to the action of xylosyltransferases (XyT) and methyltransferases (MeT), leading to unique $N$-linked structures containing methylated mannoses linked to one or two xyloses (Figure 1). The structures vary slightly among these microalgae, with different possible locations of the xylose residues [94,107,108,111]. On the other hand, Baïet and colleagues [109] demonstrated that GnT I is present and active in the diatom P. tricornutum. In this case, GnT I transfers an $N$-acetylglucosamine residue to the 5 Man and 2 GlcNAc $N$-linked protein in the Golgi apparatus. The structure is then subjected to $\alpha$-mannosidase II ( $\alpha$-Man II) and fucosyltransferase (FuT), resulting in paucimannosidic $\left(\mathrm{Man}_{3-4} \mathrm{GlcNAc}_{2}\right)$ fucosylated N-glycans [109] (Figure 1C). The GnT I-dependent pathway is also present in the green microalga Botryococcus braunii [110]. N-linked glycans in B. braunii present methylation of mannose residues (absent in P. tricornutum) and the terminal GlcNAc (linked to the $\alpha(1,3)$-mannose arm) can be attached to an additional hexose [110] (Figure 1C).

Due to the presence of a eukaryotic PTM machinery and several different glycosidases, both GnT I-independent and GnT I-dependent microalgal species show $\mathrm{N}$-glycosylation patterns more similar to humans than E. coli (glycosylation absent) and yeasts ("hyper-mannosidic" N-glycans). Nevertheless, discrepancies between human and microalgal $N$-glycans are still relevant. The absence of GnT I enzyme in GnT I-independent species is a significant issue. GnT I activity serves as starting point to produce "complex" and "hybrid" glycans, and its absence prohibits the construction of two out of three possible human N-glycan structures. Moreover, both GnT I-independent species listed here present abundant methylation of residues (absent in humans) and C. reinhardtii also presents attachment of Xyl residues, which is another immunogenic trait. Unsurprisingly, GnT I-dependent microalgae resemble human glycosylation more than GnT I-independent species. B. braunii shows native $\mathrm{N}$-glycans similar to human "hybrid" structures, and P. tricornutum presents paucimannosidic glycans, an important pattern found in a specific class of biopharmaceuticals (as explained in Section 5.1.2) $[79,112]$. Nonetheless, $\alpha(1,3)$-fucose residues in P. tricornutum [113] and methylation of mannoses in B. braunii [110] are both $\mathrm{N}$-glycan characteristics absent in humans.

\subsection{O-Glycosylation}

O-glycosylation involves an oxygen-carbon bond between the hydroxyl group of a Ser or Thr residue of the protein and the polysaccharide chain (Figure 2). There are 7 subclasses of $O$-glycans, based on which monosaccharide is directly attached to the protein [114]. In humans, the most frequently observed $O$-glycoproteins are mucins and proteoglycans $[106,114]$ (Figure 2). The first monosaccharide attached to a mucin protein is an $N$-acetylgalactosamine (GalNAc), usually followed by galactose (Gal) or a GlcNAc [106]. On the other hand, xylose is the first monosaccharide attached to a proteoglycan, followed by Gal [115]. Other important O-linked monosaccharides that can initiate the polysaccharide chain are Fuc and Man; $O$-fucosylation plays a fundamental role in transmembrane signalling $[116,117]$ and $O$-mannosylation is involved in muscle and brain development [118]. While the O-GalNAcylation starts directly in the Golgi apparatus, all the other structures begin in the ER and the whole polysaccharide is later synthesized in the Golgi, like for $N$-glycans synthesis [114].

In most organisms including humans, $\mathrm{O}$-glycosylation does not present a common structure or a consensus sequence, and many different structures are possible. Nevertheless, unique species-specific O-glycans are still recognisable in some organisms. E. coli lacks the eukaryotic organelles and PTM 
machinery to perform $O$-glycosylation [6]. O-glycans in yeasts present a core structure composed of a Man residue attached to a Ser or a Thr [119]. This structure presents a core Man with multiple mannoses attached, resulting in yeast-specific high-mannose $O$-glycans [119] (Figure 2). The majority of $\mathrm{O}$-glycans in $\mathrm{CHO}$ cells present a core structure with a GalNAc residue attached to a Ser or a Thr, the same core structure as human mucins [120]. The GalNAc residue can be further linked to a Gal or a GlcNAc residue $[120,121]$ (Figure 2). O-glycosylation core structures in plants can present a Gal residue attached to a Ser or a unique arabinose (Ara) residue attached to a hydroxyproline (Hyp) amino acid [122]. Recombinant Interferon (IFN) alpha $2 \mathrm{~b}$ expressed in tobacco cells showed a unique O-glycan pattern with a Hyp-O-Gal core and several Ara and Gal residues [123].

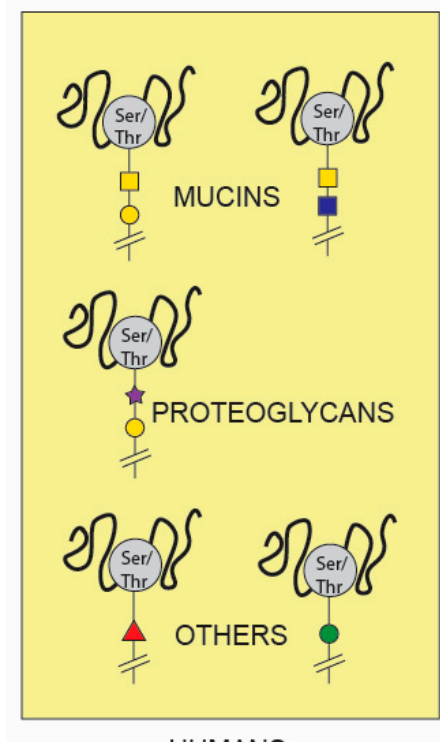

HUMANS

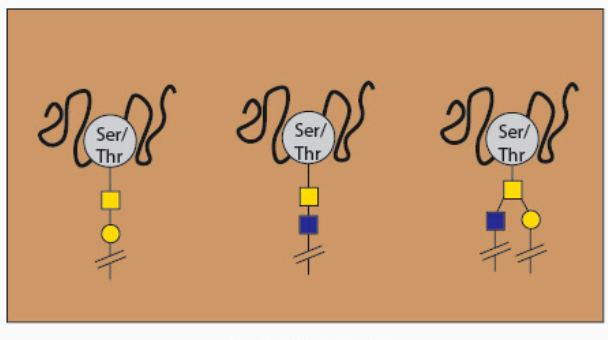

CHO CELLS

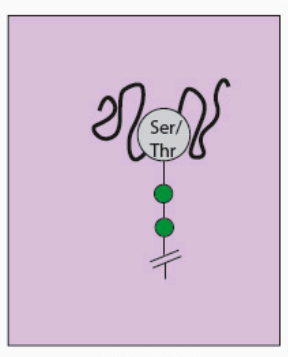

YEASTS

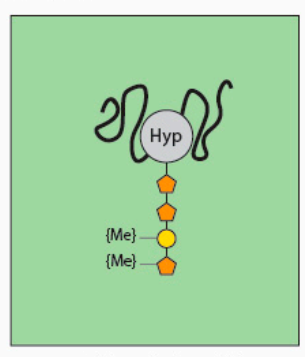

C. reinhardtii

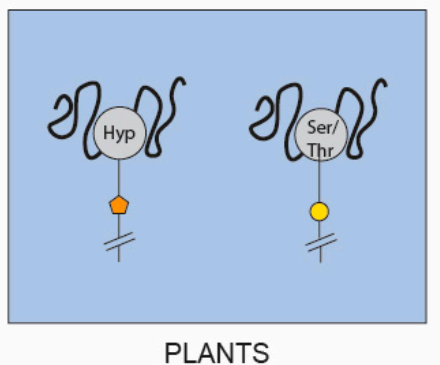

PLANTS

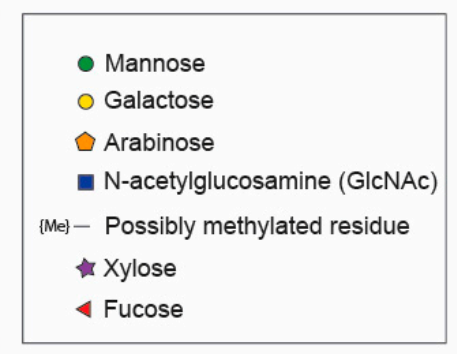

- Mannose

- Galactose

$\triangle$ Arabinose

- N-acetylglucosamine (GIcNAc)

Mej - Possibly methylated residue

\. Xylose

Figure 2. A comparison of the different $\mathrm{O}$-glycosylation patterns among humans, $\mathrm{CHO}$ cells, yeasts, plants, and microalgae. Experimental evidence for O-glycosylation in microalgae is limited to C. reinhardtii [124]. Native C. reinhardtii proteins possess a (Hyp-O-Ara-Ara) core and methylated residues, characteristics that differ significantly from human $\mathrm{O}$-glycosylation patterns. Ser/Thr = serine or threonine. Hyp = hydroxyproline. Green circle $=$ Mannose. Yellow circle $=$ Galactose. Orange pentagon $=$ Arabinose. Blue square $=$ GlcNAc . $\mathrm{Me}=$ Methylated residue. Purple star $=$ Xylose. Red triangle $=$ Fucose.

To date, there is only one study reporting O-glycosylation analysis of proteins produced in microalgae. Bollig and colleagues [124] analysed linear hydroxyproline-bound O-glycans native proteins of the green alga $C$. reinhardtii, showing similarities and differences with higher plant $O$-glycans. They found the same O-glycoprotein core as in plants (Hyp-O-Ara-Ara), suggesting conservation within the green lineage. However, they also found a higher heterogeneity of glycans in C. reinhardtii, with the presence of galactofuran residues and methylated residues (absent in plants) [124]. Based on the structures experimentally characterized, they speculated about the O-glycosylation pathways in C. reinhardtii. They proposed that two arabinosyltransferases add the first two Ara residues to Hyp, and that a galactofuranosyltransferase and two methyltransferases specific to $C$. reinhardtii perform the final modifications [124].

While there is minimal experimental information available on O-glycosylation in microalgae, existing data suggests key differences with human glycosylation patterns. C. reinhardtii native $\mathrm{O}$-glycoproteins present methylated residues on $\mathrm{O}$-glycans, a trait also found in microalgal $\mathrm{N}$-glycans but completely absent in humans. Moreover, the Hyp-O-Ara core has not been found in humans, suggesting the possibility of immunogenic activity for these types of $O$-glycans. However, further investigation of microalgal $O$-glycosylation is unquestionably needed; for example, it is not known to what extent the $C$. reinhardtii $O$-glycan core structure is immunogenic, if other species present similar 
$O$-glycan core structures, and whether these glycosylation patterns will also be found on recombinant proteins. In conclusion, more research must be conducted to unravel the $O$-glycosylation patterns in microalgae.

\subsection{Computationally Predicted Distribution of Microalgal N-and O-Glycosylation Enzymes}

Experimental evidence from a limited number of microalgal species hints at a wide diversity of $\mathrm{N}$-glycosylation patterns among different microalgal taxa. For example, the major glycosylation differences in two species (C. reinhardtii and B. braunii) belonging to the same phylum (Chlorophyta) suggest an extensive level of variation. On the other hand, it is difficult to assess the diversity of $\mathrm{O}$-glycoproteins in microalgae, as $\mathrm{O}$-glycosylation has not been adequately investigated across multiple groups. Although information from experimental characterization remains limited, computational analysis of available algal genomes permits the hypothetical reconstruction of protein $\mathrm{N}$ - and $\mathrm{O}$ glycosylation pathways (Figure 3).

\begin{tabular}{|c|c|c|c|c|c|c|c|c|c|c|}
\hline & Protein & EC number & Enzyme full name & Organism & PP & PT & NG & CR & BB & $\mathrm{cv}$ \\
\hline \multirow{13}{*}{ 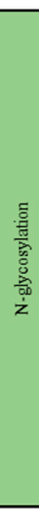 } & AMANI & 3.2.1.113 & Mannosyl-oligosaccharide 1,2-alpha-mannosidase IA & from H. sapiens & & & & & & \\
\hline & MGAT/GNT I & 2.4.1.101 & Alpha-1,3-mannosyl-glycoprotein 2-beta-N-acetylghucosaminyltransferase & from H. sapiens & & & & & & \\
\hline & AMANII & 3.2 .1 .114 & Alpha-mannosidase 2 & from H. sapiens & & & & & & \\
\hline & MGAT2/GNT II & 2.4 .1 .143 & Alpha-1,6-mannosyl-glycoprotein 2-beta-N-acetylglucosaminyltransferase & from H. sapiens & & & & & & \\
\hline & MGAT3/GNT III & 2.4.1.1.144 & Beta-1,4-mannosyl-glycoprotein 4-beta-N-acetylghucosaminyltransferase & from H. sapiens & & & & & & \\
\hline & MGAT4A/GNT IV & 2.4 .1 .145 & Alpha-1,3-mannosyl-glycoprotein 4-beta-N-acetylglucosaminyltransferase A & from H. sapiens & & & & & & \\
\hline & MGAT5/GNTV & 2.4 .1 .155 & Alpha-1,6-mannosylglycoprotein 6-beta-N-acetylglucosaminyltransferase A & from H. sapiens & & & & & & \\
\hline & FUT8 & 2.4 .1 .68 & Alpha-(1,6)-fucosyltransferase & from H. sapiens & & & & & & \\
\hline & B4GALT1 & 2.4.1.38 & $\beta$-1,4-galactosyltransferase 1 & from H. sapiens & & & & & & \\
\hline & ST3GAL3 & 2.4.99.6 & CMP-N-acetyneuraminate-beta-1,4-galactoside alpha-2,3-sialyltransferase & from H. sapiens & & & & & & \\
\hline & STGGAL1 & 2.4.99.1 & Beta-galactoside alpha-2,6-sialyltransferase 1 & from H. sapiens & & & & & & \\
\hline & FUT11 & 2.4.1.214 & Glycoprotein 3-alpha-L-fucosyltransferase A & from A. thaliana & & & & & & \\
\hline & XYLT & 2.4 .2 .38 & Beta-1,2-xylosyltransferase & from A. thaliana & & & & & & \\
\hline \multirow{10}{*}{ 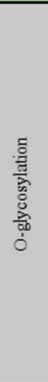 } & POMT1 & 2.4 .1 .109 & Protein O-mannosyl-transferase 1 & from H. sapiens & & & & & & \\
\hline & POMT2 & 2.4.1.109 & Protein O-mannosyl-transferase 2 & from H. sapiens & & & & & & \\
\hline & GALNT1 & 2.4.1.41 & Polypeptide $\mathrm{N}$-acetylgalactosaminyltransferase 1 & from H. sapiens & & & & & & \\
\hline & POFUT1 & 2.4.1.221 & GDP-fucose protein O-fucosyltransferase 1 & from H. sapiens & & & & & & \\
\hline & XYLT1 & 2.4.2.2. & Xylosyltransferase 1 & from H. sapiens & & & & & & \\
\hline & HPAT1 & 2.4.2.58 & Hydroxyproline O-arabinosyltransferase 1 & from A. thaliana & & & & & & \\
\hline & HPAT3 & 2.4.2.58 & Hydroxyproline O-arabinosyltransferase 3 & from A. thaliana & & & & & & \\
\hline & GALT2 & 2.4.1.- & Hydroxyproline O-galactosyltransferase GALT2 & fiom A. thaliana & & & & & & \\
\hline & SERGT1 & 2.4.1.- & Peptidyl serine alpha-galactosyltransferase & from A. thaliana & & & & & & \\
\hline & RRA1 & 2.4.2.- & Arabinosyltransferase RRA1 & from A. thaliana & & & & & & \\
\hline
\end{tabular}

Figure 3. Hypothetical presence of protein $N$-glycosylation and O-glycosylation enzymes in the representative microalgal species, P. purpureum (PP), P. tricornutum (PT), Nannochloropsis gaditana (NG), C. reinhardtii $(\mathrm{CR}), B$. braunii $(\mathrm{BB})$, and $C$. vulgaris $(\mathrm{CV})$, compared with glycosylation enzymes from H. sapiens and A. thaliana. Enzymes are classified as present (dark blue), potentially present (light blue) or missing (grey).

The genome assemblies of genomes C. reinhardtii (GCA_000002595), P.purpureum (GCA_000397085), P. tricornutum (GCF_000150955), B. braunii (GCA_002005505), C. vulgaris (GCA_001021125), and N. gaditana (GCA_000569095; GCF_000240725; GCA_001614215), were downloaded from the National Center for Biotechnology Information (NCBI). Potential Open Reading Frames (ORF) sequences were predicted on all assemblies using EMBOSS' getorf command [125]. Gene candidates were identified using the Basic Local Alignment Tool (BLAST) [126] searching all predicted ORFs for a list of candidate genes. Additionally, template genes were searched for functional domains using PFAM [127] and HMMER v3 [128]. Hit-domain motifs were downloaded and search for in the predicted ORFs. 
All candidate ORFs determined with BLAST and Pfam domain searches were finally searched and aligned on the NCBI BLASTp webpage. Sequences were classified as present if the candidate ORFs returned good hits (e-value $<1^{-05}$ ) to proteins of the same or closely related organism annotated with the exact function searched for. Sequences were classified as potentially present if: (1) only closely related proteins were identified using BLAST, but specific PFAM domains were present in the genome; (2) BLASTp returned good hits (e-value $<1^{-05}$ ) to closely related functional proteins in any other organism. All other genes were classified as missing. The glycoprofiles were hierarchically clustered using seaborn cluster map with Euclidean method in Python.

The computational analysis shown in Figure 3 supports the observation that glycosylation pathways differ significantly among diverse algal taxa, as all species investigated were predicted to have a unique combination of glycosylation enzymes. However, computational analysis only shows anticipated presence or absence of homologous enzymes and should always be supported by experimental analysis. For example, experimental analysis of glycosylation patterns of $P$. purpureum did not show activity of GnT I enzyme (Figure 1). However, GnT I is classified as present in the computational analysis. Similarly, all $O$-arabinosyltransferases from $A$. thaliana (HPAT1 and HPAT3) are classified as absent in $C$. reinhardtii (Figure 3), but core arabinose O-glycans have been detected in this microalga [124] (Figure 2). Nevertheless, computational analysis can give fundamental insight on microalgal species to be subsequently selected for further experimental analysis.

C. reinhardtii shows a very different enzyme population relative to humans and to $A$. thaliana, except for possible presence of an $O$-fucosyltransferase (POFUT1) that could result in core fucose $O$-glycans for this species. Another interesting result is the possible presence of a plant-like $N$-linked $\beta(1,2)$-xylosyltransferase (XYLT). C. reinhardtii is known to have xylose residues linked to the core GlcNAc and the antennas, and a previous study has demonstrated the presence of two xylosyltransferases, named XTA and XTB [129]. The absence of HPAT1 and HPAT3 in this microalga was unexpected, given that this microalga was shown to produce $O$-arabinose structures [124]. This suggests the potential presence of alternative enzymes in C. reinhardtii capable of linking core $O$-arabinoses.

Unlike $C$. reinhardtii, the green algae B. braunii and $C$. vulgaris show the potential presence of GnT I, which is supported by experimental analysis in B. braunii. Both species contain candidate genes for core $\alpha(1,3)$-fucosyltransferase (FUT11), which is immunogenic in humans, and its presence strongly influences the efficacy of biopharmaceuticals [93]. B. braunii is the only species to show possible presence of $\alpha(2,6)$-sialyltransferase (ST6GAL1), which is an important modification found in human proteins. The $O$-glycosylation pathway in B. braunii and C. vulgaris presents some similarities: the enzymes $O$-fucosyltransferase (POFUT1), and $O$-arabinosyltransferases from $A$. thaliana HPAT1 and HPAT3 are classified as possibly present in both species. However, the two species also show some differences. In fact, only B. braunii possibly presents homologues to the O-GalNAc transferase (GALNT1), whilst homologous enzymes of plant arabinosyltransferase (RRA1) are possibly present only in C. vulgaris.

P. purpureum shows the presence of GnT I, in contradiction with experimental data [108]. It also contains putative homologues to human $\alpha(1,6)$-fucosyltransferase (FUT8) and FUT11, which can affect biopharmaceutical efficacy [4] and immunogenicity [93], respectively. P. purpureum is predicted to have a homologue to human $\beta$-1,4-galactosyltransferase 1 (B4GALT1), which is involved in the attachment of the fundamental human residue sialic acid. However, other enzymes involved in this pathway including $\alpha(2,3)$-sialyltransferase, $\alpha(2,6)$-sialyltransferase, GnT I, GnT IV, and GnT V were not detected. For O-glycans, P. purpureum shows the potential presence of human-like $O$-mannose and $O$-GalNAc cores, and homologous enzymes of plant arabinosyltransferase (RRA1). This enzyme, however, is not involved in core $O$-arabinose linkage; core $O$-arabinose enzymes are reported as missing.

Although both species belong to the stramenopile lineage, P. tricornutum and N. gaditana vary with respect to the presence of GnT I, which has been predicted in P. tricornutum but is not detected in N. gaditana. However, both species have putative homologues for human $\alpha(1,6)$-fucosyltransferase and plant $\alpha(1,3)$-fucosyltransferase, two enzymes linked to decreased efficacy of biopharmaceuticals. 
Additionally, P. tricornutum is also predicted to harbour a homologue to plant $\beta(1,2)$-xylosyltransferase (XYLT) that may add immunogenic residues, although the presence of this enzyme was not detected experimentally [109]. Regarding O-glycosylation, both species show possible presence of enzymes involved in the attachment of $O$-xylose and $O$-fucose cores. In addition, $P$. tricornutum may also produce $O$-GalNAc cores; however, experimental analysis of $O$-glycans produced in these species is still needed.

Although the computational analysis suggests that several model algal species possess promising characteristics for biopharmaceutical production, including the presence of GnT I, several potentially problematic enzymes are also present. Albeit antigenicity of recombinant biopharmaceuticals produced in microalgae has been tested (mostly to assess proper folding and showing mixed results) [57,59,64], immunogenicity of microalgal-based therapeutics has never been tested. However, given the diversity of microalgal glycans and the predicted differences with human glycosylation profiles, "humanization" of microalgae glycans via glyco-engineering is likely needed to elicit proper folding and remove possible immunogenic glycans, to lastly produce active and safe recombinant biopharmaceuticals from microalgae [4].

\section{Strategies for Manipulating Protein Glycosylation}

In biofactories such as E. coli, yeasts, $\mathrm{CHO}$ cells, and plants, different glyco-engineering techniques have been successfully used to manipulate and "humanize" glycans to produce active and safe biopharmaceuticals for patients (E. coli: [130,131]. Yeasts: [132]. CHO cells: [133,134]. Plants: [79,135]). However, none of these techniques have yet been applied to microalgae. Glyco-engineering strategies can be divided in two main categories: protein engineering and cell engineering [97] (Figure 4). Protein glyco-engineering strategies target the recombinant glycoprotein before its translation (by modifying its DNA sequence), during its translation (by modifying its subcellular location), or after its translation (by modifying its glycosylation pattern) $[97,136]$. Cell glyco-engineering approaches introduce or modify the expression and the activity of target enzymes involved in the glycosylation pathways [97]. 


\section{A. PROTEIN GLYCO-ENGINEERING}

1. Glycoprotein sequence engineering

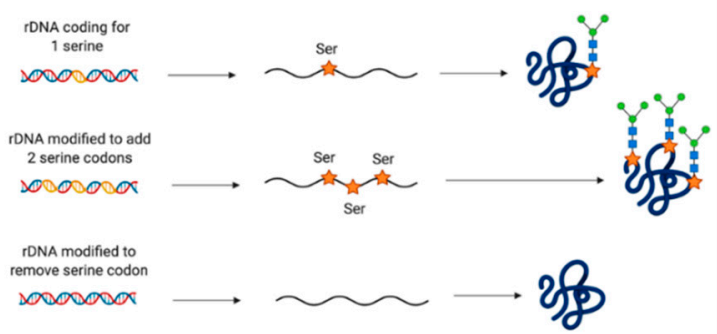

3. Glycosylation pattern engineering

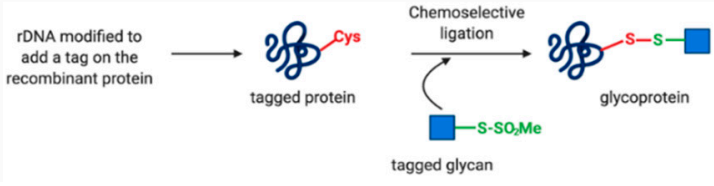

2. Sub-cellular location engineering

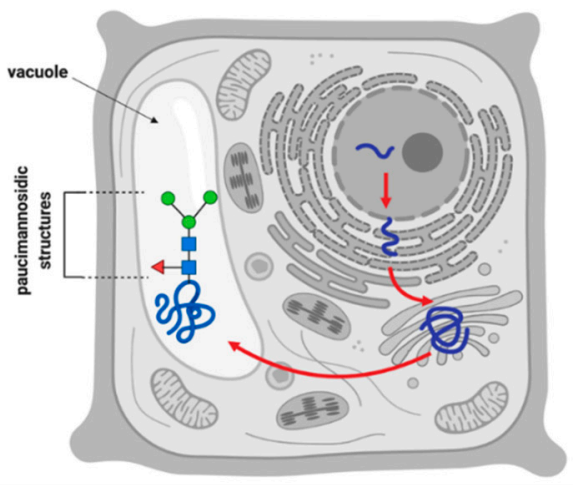

B. CELL GLYCO-ENGINEERING

1. Random genetic insertion
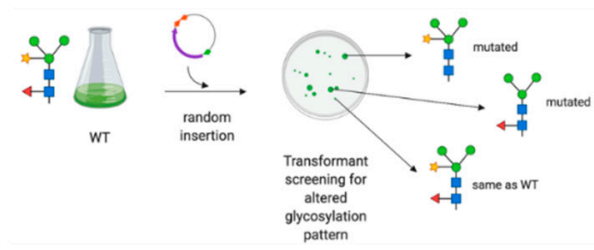

3. Inhibitor interference

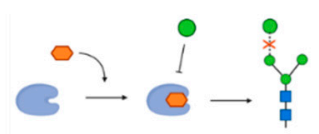

2. Targeted gene knock-in, knock-down, or knock-out

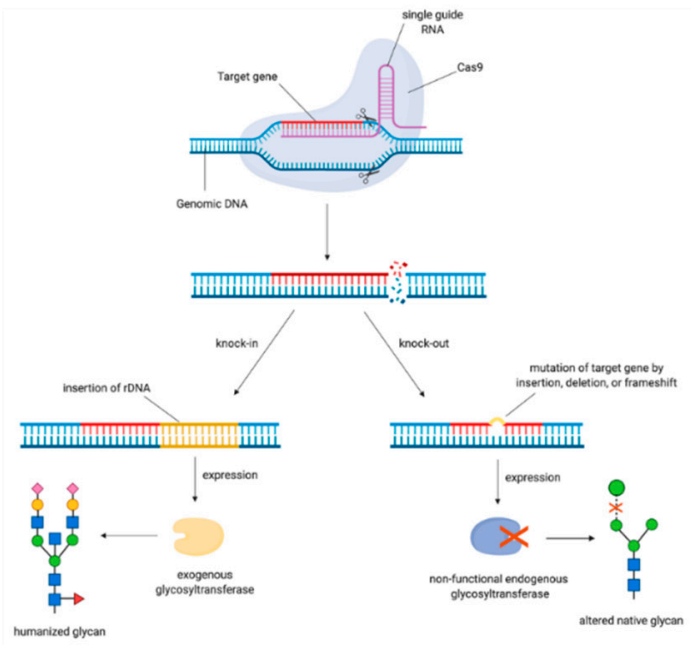

Figure 4. A schematic of different glyco-engineering strategies; (A) protein engineering and (B) cell engineering. Protein glyco-engineering approaches (A) can target (1) the recombinant DNA sequence (rDNA) [137], (2) the sub-cellular location of the biopharmaceutical [112], and (3) the glycosylation pattern of the translated protein $[138,139]$. Cell glyco-engineering strategies (B) can modify the activity of glycosylation enzymes by (1) random genetic insertion [140], (2) targeted gene knock-in or knock-out [141-145], and (3) inhibitor interference [138]. Green circle = Mannose. Blue circle = Glucose. Yellow circle $=$ Galactose. Blue square $=$ GlcNAc. Fuchsia diamond $=$ Sialic acid. Yellow star $=$ Xylose . Red triangle $=$ Fucose

\subsection{Protein Engineering}

\subsubsection{Glycoprotein Sequence Engineering}

This strategy is based on changing the amino acid sequence of a recombinant protein without changing its structure or function in the cell, to either (i) increase the number of glycans present 
or (ii) remove glycan attachment sites. The first strategy is used in the case of non-immunogenic recombinant glycoproteins in order to enhance their activity, while the second strategy prevents a protein from being glycosylated and therefore reduces its immunogenicity [137]. This approach was successful in CHO cells [146,147], and could be applied to microalgae, considering the advanced status of microalgal genetic manipulation in many different species [12]. However, this strategy presents many limitations, as altering a protein natural glycosylation is likely to cause diminished activity and stability, as demonstrated for IFN-ß [148] and for IgG-like antibody-based therapeutics [149].

\subsubsection{Subcellular Location Engineering}

Although major protein modification occurs during ER and Golgi processing, glycans can be additionally modified during transport or within other organelles [112]. Targeting and transporting a recombinant protein to a specific organelle can result in a specific glycan pattern. For example, in plants, glycoproteins targeted and transported to vacuoles present characteristic paucimannosidic $\mathrm{N}$-glycans [112]. Recombinant glucocerebrosidase (GCD), a biopharmaceutical used for Gaucher's disease treatment, was found not to be effective unless it presented paucimannosidic $N$-glycans [79]. In vivo protein glyco-engineering has been achieved by expressing a recombinant $\mathrm{GCD}$ with a C-terminal vacuole-targeting signal in transgenic carrot cells, leading to the successful production of a paucimannosidic biopharmaceutical (ELELYSO ${ }^{\circledR}$ ) [79], approved for Gaucher's disease treatment by FDA in 2012 [2]. Microalgae, like plants, possess a vacuole, therefore it might be possible to target proteins to this organelle and obtain paucimannosidic $\mathrm{N}$-glycans. Moreover, the microalga $P$. tricornutum naturally expresses paucimannosidic fucosylated N-glycans [109]. Although the function of microalgal vacuole is still under-characterized compared to higher plants [150], subcellular localization engineering might result in successful production of paucimannosidic biopharmaceuticals in microalgae. Interestingly, microalgal vacuole signal peptides for P. tricornutum have been identified [151]. However, subcellular location engineering presents a major downside: it is not possible to add/remove a targeted residue from the glycan. Therefore, this approach is strictly related to the organelle targeted for protein transportation and the resulting specific glycosylation pattern. Vacuole-targeting glyco-engineering, for example, is specific to proteins like GCD which require a paucimannosidic glycosylation pattern to be active. To remove a selected immunogenic residue, or to add a necessary residue, it is necessary to apply a different glyco-engineering approach.

\subsubsection{Glycosylation Pattern Engineering}

Glycosylation pattern engineering targets the glycan after its synthesis by trimming it to its first residue and then reconstructing a new pattern in vitro. This post-translational remodelling of the glycan can be achieved either enzymatically or chemically. These two strategies are briefly described below, but for detailed insight we refer the reader to reviews by Wang and Lomino [138] and Chalker et al. [139].

Chemoenzymatic glycan remodelling uses enzymes to both trim the pre-existing glycan and to construct the in vitro desired pattern [97]. Studies focusing on the enzymatic single step transfer of a pre-assembled glycan have shown successful results in E. coli [130,131], P. pastoris [152] and CHO cells [153].

During chemoselective and site-specific glycosylation, a tag is inserted on glycosylation sites on the amino acid backbone by site-directed mutagenesis. A glycan is then added to these tags by bio-orthogonal chemoselective ligation with a modified glycan carrying a compatible functional group. The tag on the protein and the functional group on the glycan are complementary and will selectively recognize each other, enabling a targeted insertion of glycans onto the amino acid backbone $[138,139]$ (Figure 4A). Glycosylation pattern engineering is independent of the expression host and therefore could be used in microalgae. 


\subsection{Cell Glyco-Engineering}

To produce desired human-like glycans or add crucial human residues to existing glycans, it is possible to target the species-specific glycosylation enzymes responsible for the attachment of immunogenic glycans [20-24] using cell glyco-engineering approaches. Cell glyco-engineering can be achieved by using inhibitors or genetic engineering to introduce or modify the expression of enzymes involved in glycosylation pathways $[97,138]$ (Figure 4B).

\subsubsection{Glyco-Engineering by Inhibitor Interference}

An inhibitor interference approach uses small molecules that specifically inhibit or interfere with the activity of specific enzymes in the glycosylation pathway [138] (Figure 4B). Small molecules such as N-butyl deoxynojirimycin, kifunensine, and swainsonine inhibit the activity of glycosylation enzymes such as the ER $\alpha$-glucosidases I and II, the ER $\alpha$-mannosidase-I and the Golgi $\alpha$-mannosidase II. This technique could be applied to microalgae if non-toxic inhibitors specific to microalgal glycosylation enzymes (such as fucosyltransferase and xylosyltransferase) can be identified. However, successful inhibitors might be difficult to find for these organisms, considering the evolutionary and metabolic biodiversity of microalgae. One example is the insensitivity of the diatom P. tricornutum to the activity of terbinafine (well-known inhibitor of the ubiquitous enzyme squalene epoxidase) [154,155]. Moreover, inhibitor interference strategies can only prevent the attachment of specific residues, they cannot enhance or introduce expression of human glycosylation enzymes absent in microalgae (such as the enzyme GnT I in C. reinhardtii and P. purpureum). To obtain "hybrid" or "complex" glycans it is necessary to genetically engineer the glycosylation machinery of the host organism.

\subsubsection{Genetic Glyco-Engineering}

Genetic glyco-engineering can be achieved by either introduction of heterologous glycosylation machinery or inactivation of endogenous enzymes. The integration of one or more genes coding glyco-enzymes can be achieved by random insertion or targeted knock-in (KI) of recombinant DNA into the host genome. The inserted DNA encodes specific enzymes absent in the wild type organism that will add the desired residues to the recombinant glycoprotein to obtain properly folded, active, and safe recombinant biopharmaceuticals. Although expression of exogenous enzymes has been proven as an effective strategy in CHO cells $[140,156,157]$, expression must be carefully regulated. Overexpression of glycosylation enzymes can lead to the attachment of extra residues on the glycan, possibly affecting the stability and activity of the recombinant protein.

A major technology advancement across all host systems including microalgae has been the development of targeted genome engineering aided by DNA nucleases, including zinc finger nucleases (ZFNs) [141], transcription activator-like effector nucleases (TALENs) [142], and clustered regularly interspaced short palindromic repeat/targeted Cas9 endonuclease (CRISPR-Cas9) [143-145] (Figure 4B). DNA nucleases are able to generate double stranded DNA breaks at precise genomic locations of interest, increasing the likelihood of exogenous DNA integration at a desired location, instead of at a random location. Random integration, while much easier to achieve following conventional DNA transformation strategies, is prone to position effect regarding transgene expression and uncharacterised genomic disruptions. Targeted gene integration can improve transgene expression levels when appropriate integration locations are selected; namely, regions that permit insertion of exogenous genes without disrupting the host natural gene expression whilst simultaneously lowering the risk of silencing of the exogenous DNA. Such regions, known as "safe harbours" have been frequently used in human and mouse cell lines [158-160]. Identified safe harbour loci knowledge, coupled with efficient endonuclease-mediated targeted integration transformation protocols, can revolutionise genetic engineering strategies to produce recombinant biopharmaceuticals by circumventing reproducibility and stability issues associated with random chromosomal integration [161]. 
Similar to exogenous enzyme insertion, endogenous enzyme removal strategies can be random or targeted. Gene(s) knock-down (KD) strategies result in reduced activity of the glycosylation enzymes and can be achieved by gene(s) silencing techniques, such as RNA interference [162] or CRISPR interference (CRISPRi) [163]. However, gene(s) KD does not completely inactivate enzyme expression, often resulting in still high levels of the targeted undesired enzyme activity and consequently in the attachment of the unwanted immunogenic residues. Gene(s) knock-out (KO), on the other hand, disrupts a gene that encodes a specific enzyme in the glycosylation pathway in order to permanently suppress its function [138]. Gene KO can be obtained by targeted genome editing strategies and/or random insertional mutagenesis $[164,165]$. This strategy results in loss-of-function mutant cell lines that do not produce the target enzyme, and consequently, lack the undesired residues [97]. Targeted gene(s) $\mathrm{KO}$ strategies (ZFNs and CRISPR-Cas9) were successfully used in CHO cells to inactivate the gene responsible for core-linked fucose residues (FUT8) and generate non-fucosylated glycans [133,134]. Non-fucosylated biopharmaceuticals expressed in FUT8-KO cell lines showed increased efficacy [4]. Mogamulizumab (POTELIGEO ${ }^{\circledR}$ ) and Benralizumab (MEDI-563, Fasenra ${ }^{\mathrm{TM}}$ ) are two examples of FDA approved non-fucosylated biopharmaceuticals expressed in FUT8-KO CHO cell lines [166]. However, inactivating gene(s) might have secondary detrimental effects on native proteins and consequently on the host organism.

In non-mammalian hosts, integrating human glycosylation enzymes is not sufficient to avoid the presence of immunogenic residues. Exogenous gene integration needs to be coupled with $\mathrm{KD}$ or $\mathrm{KO}$ of endogenous gene(s) coding for species-specific enzymes [97,138]. A combined approach of exogenous gene insertion and inactivation of endogenous genes was successfully used in yeasts $[132,167]$ and plants species such as Lemna minor [168], A. thaliana [135,169] and N. benthamiana [170-172].

\section{Future Perspective for Glyco-Engineering in Microalgae}

The effectiveness of glyco-engineering approaches has been demonstrated in many different organisms, both mammalian and non-mammalian, setting the stage for glyco-engineering in microalgae. However, to progress glyco-engineering strategies in microalgae, it is still necessary to improve our knowledge of microalgal glycosylation status (by genomic and experimental evidence) and thus generate a comprehensive and detailed overview of the glycosylation pathways. Unlike in common expression systems, the $\mathrm{N}$ - and $\mathrm{O}$-glycosylation pathways in microalgae have yet to be fully characterized. In this review, we provide an in silico analysis of glycosylation enzymes in five microalgal species, based on homology with higher organisms (Figure 3). These reconstructed pathways, combined with previous glycosylation analysis in other microalgal species (both empirical and putative), support the presence of a vast diversity of glycosylation patterns and can be used to identify future targets for glyco-engineering in microalgae.

An important consideration for recombinant biopharmaceutical production in microalgae is the choice of host species, as glycosylation status among microalgae has been shown to be very diverse (Sections 4.1 and 4.2). For $N$-glycans, a first selection criteria might be the presence or absence of the GnT I enzyme. GnT I-independent species show complete absence of "hybrid" and "complex" human-like glycans, whereas they still present undesired enzymes and their products (namely Xyl, Fuc, and methylation of residues). However, performing a KI of the GnT I enzyme in a GnT I-independent species lacking FuT, XyT, and MeT (based on computational analysis) might result in non-immunogenic "hybrid" and "complex" glycans. A recent study pursued this strategy in C. vulgaris and characterised "hybrid" N-glycans lacking fucose or xylose residues after overexpression of recombinant GnT I [111]. Alternatively, GnT I-dependent species already present "hybrid" and "complex" glycans. However, FuT, XyT, and MeT enzymes may still be present and active. Selection of a species that does not possess FuT, XyT, and MeT, or targeted KD or KO of these enzymes would prevent the attachment of the immunogenic residues. Species such as B. braunii and P. tricornutum are GnT I-dependent species lacking FuT, $\mathrm{XyT}$, and MeT that also have a putative $\alpha$-mannosidase II (computational analysis). These are particularly interesting candidates to produce paucimannosidic non-immunogenic glycans. 
However, this strategy is limited by native methylation of residues in B. braunii, a possibly immunogenic trait [110]. P. tricornutum, on the other hand, does not present methylated residues, but has a core $\alpha(1,3)$-fucosyltransferase. It might be effective to KD or KO the fucosyltransferase in P. tricornutum and obtain paucimannosidic non-immunogenic glycans in an already well-known and well-characterised microalgal species.

Both GnT I-independent and GnT I-dependent species are missing a very important residue present in humans: sialic acid. Enzymes such as $\alpha(2,3)$-sialyltransferase (ST3GAL3), $\alpha(2,6)$-sialyltransferase (ST6GAL1), $\beta(1,4)$-galactosyltransferase (B4GALT1), GnT I, GnT IV, and GnT V are all involved in the sialic acid pathway, and completely (or almost completely) absent in microalgae. It has been shown how overexpression of this pathway in $\mathrm{CHO}$ cells resulted in improved recombinant biopharmaceuticals production [173-175]. Figure 3 shows putative presence of some of these enzymes in some microalgal species. However, the complete pathway is absent in all the species that were computationally analysed. Furthermore, sialic acid has never been reported in any of the species experimentally analysed. Therefore, an extensive amount of glyco-engineering might be required to obtain this residue in any of these species.

The absence of a consensus sequence, a common core, and recurring patterns has made a comprehensive $O$-glycosylation immunogenicity analysis more challenging. The only glycosylation analysis available in microalgae (for $C$. reinhardtii) showed similarity with higher plants, with the addition of methylated residues. Immunogenicity of recombinant $O$-glycoproteins from plants has not been tested, however the absence of a similar $O$-glycan core in humans inspires little confidence. The computational analysis shown in Figure 3 offers interesting insight. Human $O$-xylose and $O$-fucose cores might be present in more than one microalgal species. Interestingly, microalgae and plants show limited homology (Figure 3). However, this should be considered only as a starting point for further experimental analysis of microalgal $O$-glycosylation.

Given the vast diversity of glycosylation status among microalgal species and considering the existing variety of glycans and their impact on different classes of biopharmaceuticals, it is difficult to predict a precise number of gene(s) or glyco-engineering approaches to obtain a fully "humanised" recombinant biopharmaceutical. However, based on the experimental and computational information collected, and the different successful glyco-engineering approaches utilised in other species, we postulate that producing a vacuole-targeted glucocerebrosidase in a P. tricornutum fucosyltransferase-KO cell line could be the fastest way to obtain the first commercialised recombinant biopharmaceutical from microalgae.

In conclusion, there are still major hurdles limiting glyco-engineering in microalgae. Obtaining experimental information for a single species is challenging and may very well expose immunogenic traits in the selected microalgal glycans. Some immunogenic traits may be compatible with protein or cell engineering, while others may be too complex or widespread to warrant further investigation. There is also no clear evidence to guide which microalgal species might be more appropriate in this regard over others. Moreover, considering the diversity of glycosylation among microalgae, the information obtained cannot be extended to other species, and each microalga must be experimentally investigated. However, glycosylation status of microalgae is still closer to human patterns when compared to glycosylation in bacteria and yeasts. Given the recent advancements in various model microalgal genetic toolkits, glyco-engineering approaches hold great potential to produce non-immunogenic biopharmaceuticals in microalgae.

Funding: This research received no external funding.

Conflicts of Interest: The authors declare no conflict of interest. 


\section{References}

1. Ghaderi, D.; Zhang, M.; Hurtado-Ziola, N.; Varki, A. Production platforms for biotherapeutic glycoproteins. Occurrence, impact, and challenges of non-human sialylation. Biotechnol. Genet. Eng. Rev. 2012, 28, 147-176. [CrossRef] [PubMed]

2. Walsh, G. Biopharmaceutical benchmarks 2014. Nat. Biotechnol. 2014, 32, 992. [CrossRef] [PubMed]

3. Jayapal, K.P.; Wlaschin, K.F.; Hu, W.; Yap, M.G. Recombinant protein therapeutics from CHO cells-20 years and counting. Chem. Eng. Prog. 2007, 103, 40.

4. Lalonde, M.E.; Durocher, Y. Therapeutic glycoprotein production in mammalian cells. J. Biotechnol. 2017, 251, 128-140. [CrossRef] [PubMed]

5. Hippler, M. Chlamydomonas: Biotechnology and Biomedicine; Springer: Berlin, Germany, 2017; Volume 31.

6. Baeshen, M.N.; Al-Hejin, A.M.; Bora, R.S.; Ahmed, M.M.; Ramadan, H.A.; Saini, K.S.; Baeshen, N.A.; Redwan, E.M. Production of Biopharmaceuticals in E. coli: Current Scenario and Future Perspectives. J. Microbiol. Biotechnol. 2015, 25, 953-962. [CrossRef]

7. Mattanovich, D.; Branduardi, P.; Dato, L.; Gasser, B.; Sauer, M.; Porro, D. Recombinant Protein Production in Yeasts. In Recombinant Gene Expression; Lorence, A., Ed.; Humana Press: Totowa, NJ, USA, 2012; pp. $329-358$. [CrossRef]

8. Berlec, A.; Strukelj, B. Current state and recent advances in biopharmaceutical production in Escherichia coli, yeasts and mammalian cells. J. Ind. Microbiol. Biotechnol. 2013, 40, 257-274. [CrossRef]

9. Gomord, V.; Faye, L. Posttranslational modification of therapeutic proteins in plants. Curr. Opin. Plant. Biol. 2004, 7, 171-181. [CrossRef]

10. Mathieu-Rivet, E.; Kiefer-Meyer, M.C.; Vanier, G.; Ovide, C.; Burel, C.; Lerouge, P.; Bardor, M. Protein $\mathrm{N}$-glycosylation in eukaryotic microalgae and its impact on the production of nuclear expressed biopharmaceuticals. Front. Plant. Sci. 2014, 5, 359. [CrossRef]

11. Rasala, B.A.; Mayfield, S.P. Photosynthetic biomanufacturing in green algae; production of recombinant proteins for industrial, nutritional, and medical uses. Photosynth. Res. 2015, 123, 227-239. [CrossRef]

12. Specht, E.; Miyake-Stoner, S.; Mayfield, S. Micro-algae come of age as a platform for recombinant protein production. Biotechnol. Lett. 2010, 32, 1373-1383. [CrossRef]

13. Harris, E.H. The Chlamydomonas sourcebook: Introduction to Chlamydomonas and its laboratory use; Academic press: Cambridge, MA, USA, 2009; Volume 1.

14. Hawkins, R.L.; Nakamura, M. Expression of human growth hormone by the eukaryotic alga, Chlorella. Curr. Microbiol. 1999, 38, 335-341. [CrossRef] [PubMed]

15. Bai, L.L.; Yin, W.B.; Chen, Y.H.; Niu, L.L.; Sun, Y.R.; Zhao, S.M.; Yang, F.Q.; Wang, R.R.; Wu, Q.; Zhang, X.Q.; et al. A new strategy to produce a defensin: Stable production of mutated NP-1 in nitrate reductase-deficient Chlorella ellipsoidea. PLoS ONE 2013, 8, e54966. [CrossRef] [PubMed]

16. Geng, D.; Wang, Y.; Wang, P.; Li, W.; Sun, Y. Stable expression of hepatitis B surface antigen gene in Dunaliella salina (Chlorophyta). J. Appl. Phycol. 2003, 15, 451-456. [CrossRef]

17. Chen, H.L.; Li, S.S.; Huang, R.; Tsai, H.-J. Conditional Production Of A Functional Fish Growth Hormone In The Transgenic Line Of Nannochloropsis Oculata (Eustigmatophyceae). J. Phycol. 2008, 44, 768-776. [CrossRef] [PubMed]

18. Li, S.-S.; Tsai, H.-J. Transgenic microalgae as a non-antibiotic bactericide producer to defend against bacterial pathogen infection in the fish digestive tract. Fish. Shellfish Immunol. 2009, 26, 316-325. [CrossRef]

19. Hempel, F.; Maier, U.G. An engineered diatom acting like a plasma cell secreting human IgG antibodies with high efficiency. Microb. Cell Factories 2012, 11, 126. [CrossRef]

20. Beltrao, P.; Albanese, V.; Kenner, L.R.; Swaney, D.L.; Burlingame, A.; Villen, J.; Lim, W.A.; Fraser, J.S.; Frydman, J.; Krogan, N.J. Systematic functional prioritization of protein posttranslational modifications. Cell 2012, 150, 413-425. [CrossRef]

21. Beltrao, P.; Trinidad, J.C.; Fiedler, D.; Roguev, A.; Lim, W.A.; Shokat, K.M.; Burlingame, A.L.; Krogan, N.J. Evolution of phosphoregulation: Comparison of phosphorylation patterns across yeast species. Plos Biol. 2009, 7, e1000134. [CrossRef]

22. Weinert, B.T.; Wagner, S.A.; Horn, H.; Henriksen, P.; Liu, W.R.; Olsen, J.V.; Jensen, L.J.; Choudhary, C. Proteome-Wide Mapping of the Drosophila Acetylome Demonstrates a High Degree of Conservation of Lysine Acetylation. Sci. Signal. 2011, 4, ra48. [CrossRef] 
23. Boekhorst, J.; van Breukelen, B.; Heck, A., Jr.; Snel, B. Comparative phosphoproteomics reveals evolutionary and functional conservation of phosphorylation across eukaryotes. Genome Biol. 2008, 9, R144. [CrossRef]

24. Li, Z.; Wang, Y.; Yao, Q.; Justice, N.B.; Ahn, T.H.; Xu, D.; Hettich, R.L.; Banfield, J.F.; Pan, C. Diverse and divergent protein post-translational modifications in two growth stages of a natural microbial community. Nat. Commun. 2014, 5, 4405. [CrossRef] [PubMed]

25. Bürkle, A. Posttranslational Modification. In Encyclopedia of Genetics; Brenner, S., Miller, J.H., Eds.; Academic Press: New York, NY, USA, 2001; p. 1533.

26. An, H.J.; Froehlich, J.W.; Lebrilla, C.B. Determination of glycosylation sites and site-specific heterogeneity in glycoproteins. Curr. Opin. Chem. Biol. 2009, 13, 421-426. [CrossRef] [PubMed]

27. Walsh, G.; Jefferis, R. Post-translational modifications in the context of therapeutic proteins. Nat. Biotechnol. 2006, 24, 1241-1252. [CrossRef] [PubMed]

28. Higgins, E. Carbohydrate analysis throughout the development of a protein therapeutic. Glycoconj. J. 2010, 27, 211-225. [CrossRef]

29. Butler, M.; Spearman, M. The choice of mammalian cell host and possibilities for glycosylation engineering. Curr. Opin. Biotechnol. 2014, 30, 107-112. [CrossRef]

30. Mizukami, A.; Caron, A.L.; Picanço-Castro, V.; Swiech, K. Platforms for Recombinant Therapeutic Glycoprotein Production. In Recombinant Glycoprotein Production: Methods and Protocols; Picanço-Castro, V., Swiech, K., Eds.; Springer: New York, NY, USA, 2018; pp. 1-14. [CrossRef]

31. Hajba, L.; Szekrenyes, A.; Borza, B.; Guttman, A. On the glycosylation aspects of biosimilarity. Drug Discov. Today 2018, 23, 616-625. [CrossRef]

32. Lagasse, H.A.; Alexaki, A.; Simhadri, V.L.; Katagiri, N.H.; Jankowski, W.; Sauna, Z.E.; Kimchi-Sarfaty, C. Recent advances in (therapeutic protein) drug development. F1000Research 2017, 6, 113. [CrossRef]

33. Dumont, J.; Euwart, D.; Mei, B.; Estes, S.; Kshirsagar, R. Human cell lines for biopharmaceutical manufacturing: History, status, and future perspectives. Crit. Rev. Biotechnol. 2016, 36, 1110-1122. [CrossRef]

34. Ahmad, Z.A.; Yeap, S.K.; Ali, A.M.; Ho, W.Y.; Alitheen, N.B.; Hamid, M. scFv antibody: Principles and clinical application. Clin. Dev. Immunol. 2012, 2012, 980250. [CrossRef]

35. Junutula, J.R.; Raab, H.; Clark, S.; Bhakta, S.; Leipold, D.D.; Weir, S.; Chen, Y.; Simpson, M.; Tsai, S.P.; Dennis, M.S.; et al. Site-specific conjugation of a cytotoxic drug to an antibody improves the therapeutic index. Nat. Biotechnol. 2008, 26, 925-932. [CrossRef]

36. Qiu, X.; Wong, G.; Audet, J.; Bello, A.; Fernando, L.; Alimonti, J.B.; Fausther-Bovendo, H.; Wei, H.; Aviles, J.; Hiatt, E.; et al. Reversion of advanced Ebola virus disease in nonhuman primates with ZMapp. Nature 2014, 514, 47-53. [CrossRef] [PubMed]

37. Budzianowski, J. Tobacco against Ebola virus disease. Przegl. Lek. 2015, 72, 567-571. [PubMed]

38. Davidson, E.; Bryan, C.; Fong, R.H.; Barnes, T.; Pfaff, J.M.; Mabila, M.; Rucker, J.B.; Doranz, B.J. Mechanism of Binding to Ebola Virus Glycoprotein by the ZMapp, ZMAb, and MB-003 Cocktail Antibodies. J. Virol. 2015, 89, 10982-10992. [CrossRef]

39. Cadoret, J.P.; Bernard, O. Lipid biofuel production with microalgae: Potential and challenges. J. Soc. Biol. 2008, 202, 201-211. [CrossRef]

40. Sasso, S.; Pohnert, G.; Lohr, M.; Mittag, M.; Hertweck, C. Microalgae in the postgenomic era: A blooming reservoir for new natural products. Fems Microbiol. Rev. 2012, 36, 761-785. [CrossRef]

41. Merlin, M.; Gecchele, E.; Capaldi, S.; Pezzotti, M.; Avesani, L. Comparative evaluation of recombinant protein production in different biofactories: The green perspective. Biomed. Res. Int. 2014, 2014, 136419. [CrossRef]

42. Eichler-Stahlberg, A.; Weisheit, W.; Ruecker, O.; Heitzer, M. Strategies to facilitate transgene expression in Chlamydomonas reinhardtii. Planta 2009, 229, 873-883. [CrossRef]

43. Ramos-Martinez, E.M.; Fimognari, L.; Sakuragi, Y. High-yield secretion of recombinant proteins from the microalga Chlamydomonas reinhardtii. Plant Biotechnol. J. 2017, 15, 1214-1224. [CrossRef]

44. Murbach, T.S.; Glavits, R.; Endres, J.R.; Hirka, G.; Vertesi, A.; Beres, E.; Szakonyine, I.P. A Toxicological Evaluation of Chlamydomonas reinhardtii, a Green Algae. Int J. Toxicol. 2018, 37, 53-62. [CrossRef]

45. Fields, F.J.; Ostrand, J.T.; Mayfield, S.P. Fed-batch mixotrophic cultivation of Chlamydomonas reinhardtii for high-density cultures. Algal Res. 2018, 33, 109-117. [CrossRef]

46. Fahad, S.; Khan, F.A.; Pandupuspitasari, N.S.; Ahmed, M.M.; Liao, Y.C.; Waheed, M.T.; Sameeullah, M.; Darkhshan; Hussain, S.; Saud, S.; et al. Recent developments in therapeutic protein expression technologies in plants. Biotechnol. Lett. 2015, 37, 265-279. [CrossRef] [PubMed] 
47. Scaife, M.A.; Nguyen, G.T.; Rico, J.; Lambert, D.; Helliwell, K.E.; Smith, A.G. Establishing Chlamydomonas reinhardtii as an industrial biotechnology host. Plant. J. 2015, 82, 532-546. [CrossRef] [PubMed]

48. Demurtas, O.C.; Massa, S.; Ferrante, P.; Venuti, A.; Franconi, R.; Giuliano, G. A Chlamydomonas-derived Human Papillomavirus 16 E7 vaccine induces specific tumor protection. PLoS ONE 2013, 8, e61473. [CrossRef]

49. Dreesen, I.A.; Charpin-El Hamri, G.; Fussenegger, M. Heat-stable oral alga-based vaccine protects mice from Staphylococcus aureus infection. J. Biotechnol. 2010, 145, 273-280. [CrossRef]

50. Georgianna, D.R. Production of recombinant enzymes in the marine alga Dunaliella tertiolecta. Algal Res. 2013, 2, 2-9. [CrossRef]

51. Gregory, J.A.; Li, F.; Tomosada, L.M.; Cox, C.J.; Topol, A.B.; Vinetz, J.M.; Mayfield, S. Algae-produced Pfs 25 elicits antibodies that inhibit malaria transmission. PLoS ONE 2012, 7, e37179. [CrossRef]

52. Gregory, J.A.; Topol, A.B.; Doerner, D.Z.; Mayfield, S. Alga-produced cholera toxin-Pfs25 fusion proteins as oral vaccines. Appl. Env. Microbiol. 2013, 79, 3917-3925. [CrossRef]

53. He, D.M.; Qian, K.X.; Shen, G.F.; Zhang, Z.F.; Li, Y.N.; Su, Z.L.; Shao, H.B. Recombination and expression of classical swine fever virus (CSFV) structural protein E2 gene in Chlamydomonas reinhardtii chroloplasts. Colloids Surf. B. Biointerfaces 2007, 55, 26-30. [CrossRef]

54. Jones, C.S.; Luong, T.; Hannon, M.; Tran, M.; Gregory, J.A.; Shen, Z.; Briggs, S.P.; Mayfield, S.P. Heterologous expression of the C-terminal antigenic domain of the malaria vaccine candidate Pfs $48 / 45$ in the green algae Chlamydomonas reinhardtii. Appl. Microbiol. Biotechnol. 2013, 97, 1987-1995. [CrossRef]

55. Manuell, A.L.; Beligni, M.V.; Elder, J.H.; Siefker, D.T.; Tran, M.; Weber, A.; McDonald, T.L.; Mayfield, S.P. Robust expression of a bioactive mammalian protein in Chlamydomonas chloroplast. Plant. Biotechnol. J. 2007, 5, 402-412. [CrossRef]

56. Mayfield, S.P.; Franklin, S.E.; Lerner, R.A. Expression and assembly of a fully active antibody in algae. Proc. Natl. Acad. Sci. USA 2003, 100, 438-442. [CrossRef]

57. Rasala, B.A.; Muto, M.; Lee, P.A.; Jager, M.; Cardoso, R.M.; Behnke, C.A.; Kirk, P.; Hokanson, C.A.; Crea, R.; Mendez, M.; et al. Production of therapeutic proteins in algae, analysis of expression of seven human proteins in the chloroplast of Chlamydomonas reinhardtii. Plant. Biotechnol. J. 2010, 8, 719-733. [CrossRef]

58. Su, Z.L.; Qian, K.X.; Tan, C.P.; Meng, C.X.; Qin, S. Recombination and heterologous expression of allophycocyanin gene in the chloroplast of Chlamydomonas reinhardtii. Acta Biochim. Biophys. Sin. (Shanghai) 2005, 37, 709-712. [CrossRef]

59. Sun, M.; Qian, K.; Su, N.; Chang, H.; Liu, J.; Shen, G. Foot-and-mouth disease virus VP1 protein fused with cholera toxin B subunit expressed in Chlamydomonas reinhardtii chloroplast. Biotechnol Lett. 2003, 25, 1087-1092. [CrossRef]

60. Surzycki, R.; Greenham, K.; Kitayama, K.; Dibal, F.; Wagner, R.; Rochaix, J.D.; Ajam, T.; Surzycki, S. Factors effecting expression of vaccines in microalgae. Biologicals 2009, 37, 133-138. [CrossRef]

61. Tran, M.; Zhou, B.; Pettersson, P.L.; Gonzalez, M.J.; Mayfield, S.P. Synthesis and assembly of a full-length human monoclonal antibody in algal chloroplasts. Biotechnol. Bioeng. 2009, 104, 663-673. [CrossRef]

62. Tran, M.; Henry, R.E.; Siefker, D.; Van, C.; Newkirk, G.; Kim, J.; Bui, J.; Mayfield, S.P. Production of anti-cancer immunotoxins in algae: Ribosome inactivating proteins as fusion partners. Biotechnol. Bioeng. 2013, 110, 2826-2835. [CrossRef]

63. Tran, M.; Van, C.; Barrera, D.J.; Pettersson, P.L.; Peinado, C.D.; Bui, J.; Mayfield, S.P. Production of unique immunotoxin cancer therapeutics in algal chloroplasts. Proc. Natl. Acad. Sci. USA 2013, 110, E15-E22. [CrossRef]

64. Wang, X.; Brandsma, M.; Tremblay, R.; Maxwell, D.; Jevnikar, A.M.; Huner, N.; Ma, S. A novel expression platform for the production of diabetes-associated autoantigen human glutamic acid decarboxylase (hGAD65). Bmc Biotechnol 2008, 8, 87. [CrossRef]

65. Yang, Z.; Li, y.; Chen, F.; Li, D.; Zhang, Z.; Liu, Y.; Zheng, D.; Wang, Y.; Shen, G. Expression of human soluble TRAIL in Chlamydomonas reinhardtii chloroplast. Chin. Sci. Bull. 2006, 51, 1703-1709. [CrossRef]

66. Yoon, S.M.; Kim, S.Y.; Li, K.F.; Yoon, B.H.; Choe, S.; Kuo, M.M. Transgenic microalgae expressing Escherichia coli AppA phytase as feed additive to reduce phytate excretion in the manure of young broiler chicks. Appl. Microbiol. Biotechnol 2011, 91, 553-563. [CrossRef]

67. Zhang, Y.K.; Shen, G.F.; Ru, B.G. Survival of human metallothionein-2 transplastomic Chlamydomonas reinhardtii to ultraviolet B exposure. Acta Biochim. Biophys. Sin. (Shanghai) 2006, 38, 187-193. [CrossRef] 
68. Baier, T.; Kros, D.; Feiner, R.C.; Lauersen, K.J.; Muller, K.M.; Kruse, O. Engineered Fusion Proteins for Efficient Protein Secretion and Purification of a Human Growth Factor from the Green Microalga Chlamydomonas reinhardtii. Acs Synth Biol 2018. [CrossRef]

69. Chavez, M.N.; Schenck, T.L.; Hopfner, U.; Centeno-Cerdas, C.; Somlai-Schweiger, I.; Schwarz, C.; Machens, H.G.; Heikenwalder, M.; Bono, M.R.; Allende, M.L.; et al. Towards autotrophic tissue engineering: Photosynthetic gene therapy for regeneration. Biomaterials 2016, 75, 25-36. [CrossRef]

70. Dauvillee, D.; Delhaye, S.; Gruyer, S.; Slomianny, C.; Moretz, S.E.; d’Hulst, C.; Long, C.A.; Ball, S.G.; Tomavo, S. Engineering the chloroplast targeted malarial vaccine antigens in Chlamydomonas starch granules. PLoS ONE 2010, 5, e15424. [CrossRef]

71. Hou, Q.; Qiu, S.; Liu, Q.; Tian, J.; Hu, Z.; Ni, J. Selenoprotein-transgenic Chlamydomonas reinhardtii. Nutrients 2013, 5, 624-636. [CrossRef]

72. Lauersen, K.J.; Vanderveer, T.L.; Berger, H.; Kaluza, I.; Mussgnug, J.H.; Walker, V.K.; Kruse, O. Ice recrystallization inhibition mediated by a nuclear-expressed and -secreted recombinant ice-binding protein in the microalga Chlamydomonas reinhardtii. Appl. Microbiol. Biotechnol. 2013, 97, 9763-9772. [CrossRef]

73. Rasala, B.A.; Lee, P.A.; Shen, Z.; Briggs, S.P.; Mendez, M.; Mayfield, S.P. Robust expression and secretion of Xylanase1 in Chlamydomonas reinhardtii by fusion to a selection gene and processing with the FMDV 2A peptide. PLoS ONE 2012, 7, e43349. [CrossRef]

74. Chen, Y.; Wang, Y.; Sun, Y.; Zhang, L.; Li, W. Highly efficient expression of rabbit neutrophil peptide-1 gene in Chlorella ellipsoidea cells. Curr Genet. 2001, 39, 365-370. [CrossRef]

75. Kim, D.H.; Kim, Y.T.; Cho, J.J.; Bae, J.H.; Hur, S.B.; Hwang, I.; Choi, T.J. Stable integration and functional expression of flounder growth hormone gene in transformed microalga, Chlorella ellipsoidea. Mar. Biotechnol (NY) 2002, 4, 63-73. [CrossRef]

76. Feng, S.; Feng, W.; Zhao, L.; Gu, H.; Li, Q.; Shi, K.; Guo, S.; Zhang, N. Preparation of transgenic Dunaliella salina for immunization against white spot syndrome virus in crayfish. Arch. Virol 2014, 159, 519-525. [CrossRef]

77. Hempel, F.; Maurer, M.; Brockmann, B.; Mayer, C.; Biedenkopf, N.; Kelterbaum, A.; Becker, S.; Maier, U.G. From hybridomas to a robust microalgal-based production platform: Molecular design of a diatom secreting monoclonal antibodies directed against the Marburg virus nucleoprotein. Microb. Cell Fact. 2017, 16, 131. [CrossRef]

78. Walsh, G. Biopharmaceutical benchmarks 2018. Nat. Biotechnol 2018, 36, 1136-1145. [CrossRef]

79. Shaaltiel, Y.; Bartfeld, D.; Hashmueli, S.; Baum, G.; Brill-Almon, E.; Galili, G.; Dym, O.; Boldin-Adamsky, S.A.; Silman, I.; Sussman, J.L.; et al. Production of glucocerebrosidase with terminal mannose glycans for enzyme replacement therapy of Gaucher's disease using a plant cell system. Plant. Biotechnol. J. 2007, 5, 579-590. [CrossRef]

80. New antibodies best ZMapp in Ebola trial. Nat. Biotechnol. 2019, 37, 1105. [CrossRef]

81. Walsh, C.T.; Garneau-Tsodikova, S.; Gatto, G.J., Jr. Protein posttranslational modifications: The chemistry of proteome diversifications. Angew. Chem. Int. Ed. Engl. 2005, 44, 7342-7372. [CrossRef]

82. Amoresano, A.; Carpentieri, A.; Giangrande, C.; Palmese, A.; Chiappetta, G.; Marino, G.; Pucci, P. Technical advances in proteomics mass spectrometry: Identification of post-translational modifications. Clin. Chem. Lab. Med. 2009, 47, 647-665. [CrossRef]

83. Deribe, Y.L.; Pawson, T.; Dikic, I. Post-translational modifications in signal integration. Nat. Struct. Mol. Biol. 2010, 17, 666-672. [CrossRef]

84. Nikov, G.; Bhat, V.; Wishnok, J.S.; Tannenbaum, S.R. Analysis of nitrated proteins by nitrotyrosine-specific affinity probes and mass spectrometry. Anal. Biochem. 2003, 320, 214-222. [CrossRef]

85. Swaney, D.L.; Beltrao, P.; Starita, L.; Guo, A.; Rush, J.; Fields, S.; Krogan, N.J.; Villen, J. Global analysis of phosphorylation and ubiquitylation cross-talk in protein degradation. Nat. Methods 2013, 10, 676-682. [CrossRef]

86. Uversky, V.N. Wrecked regulation of intrinsically disordered proteins in diseases: Pathogenicity of deregulated regulators. Front. Mol. Biosci. 2014, 1, 6. [CrossRef] [PubMed]

87. Ohtsubo, K.; Marth, J.D. Glycosylation in cellular mechanisms of health and disease. Cell 2006, 126, 855-867. [CrossRef] [PubMed]

88. Jefferis, R. Glycosylation as a strategy to improve antibody-based therapeutics. Nat. Rev. Drug Discov. 2009, 8, 226-234. [CrossRef] 
89. Shields, R.L.; Lai, J.; Keck, R.; O'Connell, L.Y.; Hong, K.; Meng, Y.G.; Weikert, S.H.; Presta, L.G. Lack of fucose on human IgG1 N-linked oligosaccharide improves binding to human Fc $\gamma$ RIII and antibody-dependent cellular toxicity. J. Biol. Chem. 2002, 277, 26733-26740. [CrossRef]

90. Niwa, R.; Natsume, A.; Uehara, A.; Wakitani, M.; Iida, S.; Uchida, K.; Satoh, M.; Shitara, K. IgG subclass-independent improvement of antibody-dependent cellular cytotoxicity by fucose removal from Asn297-linked oligosaccharides. J. Immunol. Methods 2005, 306, 151-160. [CrossRef]

91. Shinkawa, T.; Nakamura, K.; Yamane, N.; Shoji-Hosaka, E.; Kanda, Y.; Sakurada, M.; Uchida, K.; Anazawa, H.; Satoh, M.; Yamasaki, M. The absence of fucose but not the presence of galactose or bisecting N-acetylglucosamine of human IgG1 complex-type oligosaccharides shows the critical role of enhancing antibody-dependent cellular cytotoxicity. J. Biol. Chem. 2003, 278, 3466-3473. [CrossRef]

92. Kessler, M.; Goldsmith, D.; Schellekens, H. Immunogenicity of biopharmaceuticals. Nephrol Dial. Transpl. 2006, 21 (Suppl. 5), v9-v12. [CrossRef]

93. van Beers, M.M.C.; Bardor, M. Minimizing immunogenicity of biopharmaceuticals by controlling critical quality attributes of proteins. Biotechnol. J. 2012, 7, 1473-1484. [CrossRef]

94. Vanier, G.; Lucas, P.L.; Loutelier-Bourhis, C.; Vanier, J.; Plasson, C.; Walet-Balieu, M.L.; Tchi-Song, P.C.; Remy-Jouet, I.; Richard, V.; Bernard, S.; et al. Heterologous expression of the N-acetylglucosaminyltransferase I dictates a reinvestigation of the N-glycosylation pathway in Chlamydomonas reinhardtii. Sci. Rep. 2017, 7, 10156. [CrossRef]

95. Marshall, R.D. The nature and metabolism of the carbohydrate-peptide linkages of glycoproteins. Biochem. Soc. Symp. 1974, 17-26.

96. Zielinska, D.F.; Gnad, F.; Wisniewski, J.R.; Mann, M. Precision mapping of an in vivo N-glycoproteome reveals rigid topological and sequence constraints. Cell 2010, 141, 897-907. [CrossRef]

97. Costa, A.R.; Rodrigues, M.E.; Henriques, M.; Oliveira, R.; Azeredo, J. Glycosylation: Impact, control and improvement during therapeutic protein production. Crit. Rev. Biotechnol. 2014, 34, 281-299. [CrossRef]

98. Parodi, A.J. Role of N-oligosaccharide endoplasmic reticulum processing reactions in glycoprotein folding and degradation. Biochem. J. 2000, 348, 1. [CrossRef]

99. Dell, A.; Morris, H.R. Glycoprotein Structure Determination by Mass Spectrometry. Science 2001, $291,2351$. [CrossRef]

100. Harvey, D.J. Analysis of carbohydrates and glycoconjugates by matrix-assisted laser desorption/ionization mass spectrometry: An update for 2011-2012. Mass Spectrom. Rev. 2015. [CrossRef]

101. Varelas, X.; Bouchie, M.P.; Kukuruzinska, M.A. Protein N-glycosylation in oral cancer: Dysregulated cellular networks among DPAGT1, E-cadherin adhesion and canonical Wnt signaling. Glycobiology 2014, 24, 579-591. [CrossRef]

102. Wacker, M.; Linton, D.; Hitchen, P.G.; Nita-Lazar, M.; Haslam, S.M.; North, S.J.; Panico, M.; Morris, H.R.; Dell, A.; Wren, B.W.; et al. N-linked glycosylation in Campylobacter jejuni and its functional transfer into E. coli. (Reports). Science 2002, 298, 1790-1793. [CrossRef]

103. Linton, D.; Dorrell, N.; Hitchen, P.G.; Amber, S.; Karlyshev, A.V.; Morris, H.R.; Dell, A.; Valvano, M.A.; Aebi, M.; Wren, B.W. Functional analysis of the Campylobacter jejuni N-linked protein glycosylation pathway. Mol. Microbiol 2005, 55, 1695-1703. [CrossRef]

104. Tang, H.; Wang, S.; Wang, J.; Song, M.; Xu, M.; Zhang, M.; Shen, Y.; Hou, J.; Bao, X. N-hypermannose glycosylation disruption enhances recombinant protein production by regulating secretory pathway and cell wall integrity in Saccharomyces cerevisiae. Sci Rep. 2016, 6, 25654. [CrossRef]

105. Parsaie Nasab, F.; Aebi, M.; Bernhard, G.; Frey, A.D. A combined system for engineering glycosylation efficiency and glycan structure in Saccharomyces cerevisiae. Appl Env. Microbiol 2013, 79, 997-1007. [CrossRef]

106. Gomord, V.; Fitchette, A.C.; Menu-Bouaouiche, L.; Saint-Jore-Dupas, C.; Plasson, C.; Michaud, D.; Faye, L. Plant-specific glycosylation patterns in the context of therapeutic protein production. Plant. Biotechnol. J. 2010, 8, 564-587. [CrossRef] [PubMed]

107. Mathieu-Rivet, E.; Scholz, M.; Arias, C.; Dardelle, F.; Schulze, S.; Le Mauff, F.; Teo, G.; Hochmal, A.K.; Blanco-Rivero, A.; Loutelier-Bourhis, C.; et al. Exploring the N-glycosylation pathway in Chlamydomonas reinhardtii unravels novel complex structures. Mol. Cell Proteom. 2013, 12, 3160-3183. [CrossRef] [PubMed]

108. Levy-Ontman, O.; Arad, S.M.; Harvey, D.J.; Parsons, T.B.; Fairbanks, A.; Tekoah, Y. Unique N-glycan moieties of the 66-kDa cell wall glycoprotein from the red microalga Porphyridium sp. J. Biol. Chem. 2011, 286, 21340-21352. [CrossRef] [PubMed] 
109. Baiet, B.; Burel, C.; Saint-Jean, B.; Louvet, R.; Menu-Bouaouiche, L.; Kiefer-Meyer, M.C.; Mathieu-Rivet, E.; Lefebvre, T.; Castel, H.; Carlier, A.; et al. N-glycans of Phaeodactylum tricornutum diatom and functional characterization of its N-acetylglucosaminyltransferase I enzyme. J. Biol. Chem. 2011, 286, 6152-6164. [CrossRef] [PubMed]

110. Schulze, S.; Urzica, E.; Reijnders, M.; van de Geest, H.; Warris, S.; Bakker, L.V.; Fufezan, C.; Martins Dos Santos, V.A.P.; Schaap, P.J.; Peters, S.A.; et al. Identification of methylated GnTI-dependent N-glycans in Botryococcus brauni. New Phytol. 2017, 215, 1361-1369. [CrossRef]

111. Mocsai, R.; Figl, R.; Troschl, C.; Strasser, R.; Svehla, E.; Windwarder, M.; Thader, A.; Altmann, F. N-glycans of the microalga Chlorella vulgaris are of the oligomannosidic type but highly methylated. Sci. Rep. 2019, 9, 331. [CrossRef]

112. Lerouge, P.; Cabanes-Macheteau, M.; Rayon, C.; Fischette-Lainé, A.-C.; Gomord, V.; Faye, L. N-Glycoprotein biosynthesis in plants: Recent developments and future trends. Plant. Mol. Biol. 1998, 38, 31-48. [CrossRef]

113. Zhang, P.; Burel, C.; Plasson, C.; Kiefer-Meyer, M.C.; Ovide, C.; Gugi, B.; Wan, C.; Teo, G.; Mak, A.; Song, Z.; et al. Characterization of a GDP-Fucose Transporter and a Fucosyltransferase Involved in the Fucosylation of Glycoproteins in the Diatom Phaeodactylum tricornutum. Front. Plant. Sci 2019, 10, 610. [CrossRef]

114. Nakayama, Y.; Nakamura, N.; Tsuji, D.; Itoh, K.; Kurosak, A. Genetic Diseases Associated with Protein Glycosylation Disorders in Mammals. Genetic Disorders 2013. [CrossRef]

115. Yusibov, V.; Kushnir, N.; Streatfield, S.J. Antibody Production in Plants and Green Algae. Annu Rev. Plant. Biol 2016, 67, 669-701. [CrossRef]

116. Mumm, J.S.; Kopan, R. Notch signaling: From the outside in. Dev. Biol 2000, 228, 151-165. [CrossRef] [PubMed]

117. Rana, N.A.; Haltiwanger, R.S. Fringe benefits: Functional and structural impacts of O-glycosylation on the extracellular domain of Notch receptors. Curr. Opin. Struct. Biol. 2011, 21, 583-589. [CrossRef] [PubMed]

118. Dobson, C.M.; Hempel, S.J.; Stalnaker, S.H.; Stuart, R.; Wells, L. O-Mannosylation and human disease. Cell Mol. Life Sci. 2013, 70, 2849-2857. [CrossRef] [PubMed]

119. De Pourcq, K.; De Schutter, K.; Callewaert, N. Engineering of glycosylation in yeast and other fungi: Current state and perspectives. Appl. Microbiol. Biotechnol. 2010, 87, 1617-1631. [CrossRef]

120. Liu, J.; Jin, C.; Cherian, R.M.; Karlsson, N.G.; Holgersson, J. O-glycan repertoires on a mucin-type reporter protein expressed in $\mathrm{CHO}$ cell pools transiently transfected with O-glycan core enzyme cDNAs. J. Biotechnol. 2015, 199, 77-89. [CrossRef]

121. Mitoma, J.; Petryniak, B.; Hiraoka, N.; Yeh, J.C.; Lowe, J.B.; Fukuda, M. Extended core 1 and core 2 branched O-glycans differentially modulate sialyl Lewis X-type L-selectin ligand activity. J. Biol. Chem. 2003, 278, 9953-9961. [CrossRef]

122. Nguema-Ona, E.; Vicre-Gibouin, M.; Gotte, M.; Plancot, B.; Lerouge, P.; Bardor, M.; Driouich, A. Cell wall O-glycoproteins and N-glycoproteins: Aspects of biosynthesis and function. Front. Plant. Sci. 2014, 5, 499. [CrossRef]

123. Xu, J.; Tan, L.; Goodrum, K.J.; Kieliszewski, M.J. High-yields and extended serum half-life of human interferon alpha2b expressed in tobacco cells as arabinogalactan-protein fusions. Biotechnol. Bioeng. 2007, 97, 997-1008. [CrossRef]

124. Bollig, K.; Lamshoft, M.; Schweimer, K.; Marner, F.J.; Budzikiewicz, H.; Waffenschmidt, S. Structural analysis of linear hydroxyproline-bound O-glycans of Chlamydomonas reinhardtii-conservation of the inner core in Chlamydomonas and land plants. Carbohydr. Res. 2007, 342, 2557-2566. [CrossRef]

125. Rice, P.; Longden, I.; Bleasby, A. EMBOSS: The European Molecular Biology Open Software Suite. Trends Genet. 2000, 16, 276-277. [CrossRef]

126. Altschul, S.F.; Gish, W.; Miller, W.; Myers, E.W.; Lipman, D.J. Basic local alignment search tool. J. Mol. Biol. 1990, 215, 403-410. [CrossRef]

127. El-Gebali, S.; Mistry, J.; Bateman, A.; Eddy, S.R.; Luciani, A.; Potter, S.C.; Qureshi, M.; Richardson, L.J.; Salazar, G.A.; Smart, A.; et al. The Pfam protein families database in 2019. Nucleic Acids Res. 2019, 47, D427-D432. [CrossRef] [PubMed]

128. Johnson, L.S.; Eddy, S.R.; Portugaly, E. Hidden Markov model speed heuristic and iterative HMM search procedure. BMC Bioinform. 2010, 11, 431. [CrossRef] [PubMed] 
129. Lucas, P.-L.; Mathieu-Rivet, E.; Chan Tchi Song, P.; Oltmanns, A.; Loutelier-Bourhis, C.; Plasson, C.; Afonso, C.; Hippler, M.; Lerouge, P.; Mati-Baouche, N.; et al. Multiple xylosyltransferases heterogeneously xylosylate protein N-linked glycans in Chlamydomonas reinhardtii. Plant. J. 2019. [CrossRef]

130. Kowarik, M.; Young, N.M.; Numao, S.; Schulz, B.L.; Hug, I.; Callewaert, N.; Mills, D.C.; Watson, D.C.; Hernandez, M.; Kelly, J.F.; et al. Definition of the bacterial N-glycosylation site consensus sequence. EMBO J. 2006, 25, 1957-1966. [CrossRef]

131. Schwarz, D.; Daley, D.; Beckhaus, T.; Dötsch, V.; Bernhard, F. Cell-free expression profiling of E. coli inner membrane proteins. Proteomics 2010, 10, 1762-1779. [CrossRef]

132. Hamilton, S.R.; Davidson, R.C.; Sethuraman, N.; Nett, J.H.; Jiang, Y.; Rios, S.; Bobrowicz, P.; Stadheim, T.A.; Li, H.; Choi, B.K.; et al. Humanization of yeast to produce complex terminally sialylated glycoproteins. Science 2006, 313, 1441-1443. [CrossRef]

133. Malphettes, L.; Freyvert, Y.; Chang, J.; Liu, P.Q.; Chan, E.; Miller, J.C.; Zhou, Z.; Nguyen, T.; Tsai, C.; Snowden, A.W.; et al. Highly efficient deletion of FUT8 in CHO cell lines using zinc-finger nucleases yields cells that produce completely nonfucosylated antibodies. Biotechnol. Bioeng. 2010, 106, 774-783. [CrossRef]

134. Ronda, C.; Pedersen, L.E.; Hansen, H.G.; Kallehauge, T.B.; Betenbaugh, M.J.; Nielsen, A.T.; Kildegaard, H.F. Accelerating genome editing in CHO cells using CRISPR Cas9 and CRISPy, a web-based target finding tool. Biotechnol. Bioeng. 2014, 111, 1604-1616. [CrossRef]

135. Piron, R.; Santens, F.; De Paepe, A.; Depicker, A.; Callewaert, N. Using GlycoDelete to produce proteins lacking plant-specific N-glycan modification in seeds. Nat. Biotechnol. 2015, 33, 1135. [CrossRef]

136. Castilho, A.; Steinkellner, H. Glyco-engineering in plants to produce human-like N-glycan structures. Biotechnol J. 2012, 7, 1088-1098. [CrossRef] [PubMed]

137. Zhou, Q.; Shankara, S.; Roy, A.; Qiu, H.; Estes, S.; McVie-Wylie, A.; Culm-Merdek, K.; Park, A.; Pan, C.; Edmunds, T. Development of a simple and rapid method for producing non-fucosylated oligomannose containing antibodies with increased effector function. Biotechnol. Bioeng. 2008, 99, 652-665. [CrossRef] [PubMed]

138. Wang, L.X.; Lomino, J.V. Emerging technologies for making glycan-defined glycoproteins. ACS Chem. Biol. 2012, 7, 110-122. [CrossRef] [PubMed]

139. Chalker, J.M.; Bernardes, G.J.L.; Davis, B.G. A “Tag-and-Modify” Approach to Site-Selective Protein Modification. Acc. Chem. Res. 2011, 44, 730-741. [CrossRef] [PubMed]

140. Narasimhan, S. Control of glycoprotein synthesis. UDP-GlcNAc:glycopeptide beta 4-N-acetylglucosaminyltransferase III, an enzyme in hen oviduct which adds GlcNAc in beta 1-4 linkage to the beta-linked mannose of the trimannosyl core of N-glycosyl oligosaccharides. J. Biol. Chem. 1982, 257, 10235-10242.

141. Sizova, I.; Greiner, A.; Awasthi, M.; Kateriya, S.; Hegemann, P. Nuclear gene targeting in Chlamydomonas using engineered zinc-finger nucleases. Plant J. 2013, 73, 873-882. [CrossRef]

142. Daboussi, F.; Leduc, S.; Marechal, A.; Dubois, G.; Guyot, V.; Perez-Michaut, C.; Amato, A.; Falciatore, A.; Juillerat, A.; Beurdeley, M.; et al. Genome engineering empowers the diatom Phaeodactylum tricornutum for biotechnology. Nat. Commun. 2014, 5, 3831. [CrossRef]

143. Jiang, W.; Bikard, D.; Cox, D.; Zhang, F.; Marraffini, L.A. RNA-guided editing of bacterial genomes using CRISPR-Cas systems. Nat. Biotechnol 2013, 31, 233-239. [CrossRef]

144. Nymark, M.; Sharma, A.K.; Sparstad, T.; Bones, A.M.; Winge, P. A CRISPR/Cas9 system adapted for gene editing in marine algae. Sci. Rep. 2016, 6, 24951. [CrossRef]

145. Wang, Q.; Lu, Y.; Xin, Y.; Wei, L.; Huang, S.; Xu, J. Genome editing of model oleaginous microalgae Nannochloropsis spp. by CRISPR/Cas9. Plant. J. 2016, 88, 1071-1081. [CrossRef]

146. Elliott, S.; Lorenzini, T.; Asher, S.; Aoki, K.; Brankow, D.; Buck, L.; Busse, L.; Chang, D.; Fuller, J.; Grant, J.; et al. Enhancement of therapeutic protein in vivo activities through glycoengineering. Nat. Biotechnol. 2003, 21, 414-421. [CrossRef] [PubMed]

147. Perlman, S.; van den Hazel, B.; Christiansen, J.; Gram-Nielsen, S.; Jeppesen, C.B.; Andersen, K.V.; Halkier, T.; Okkels, S.; Schambye, H.T. Glycosylation of an N-Terminal Extension Prolongs the Half-Life and Increases the in Vivo Activity of Follicle Stimulating Hormone. J. Clin. Endocrinol. Metab. 2003, 88, 3227-3235. [CrossRef] [PubMed]

148. Runkel, L.; Meier, W.; Pepinsky, R.B.; Karpusas, M.; Whitty, A.; Kimball, K.; Brickelmaier, M.; Muldowney, C.; Jones, W.; Goelz, S.E. Structural and Functional Differences Between Glycosylated and Non-glycosylated Forms of Human Interferon- $\beta$ (IFN- $\beta$ ). Pharm. Res. 1998, 15, 641-649. [CrossRef] [PubMed] 
149. Sola, R.J.; Griebenow, K. Effects of glycosylation on the stability of protein pharmaceuticals. J. Pharm. Sci. 2009, 98, 1223-1245. [CrossRef]

150. Shebanova, A.; Ismagulova, T.; Solovchenko, A.; Baulina, O.; Lobakova, E.; Ivanova, A.; Moiseenko, A.; Shaitan, K.; Polshakov, V.; Nedbal, L.; et al. Versatility of the green microalga cell vacuole function as revealed by analytical transmission electron microscopy. Protoplasma 2017, 254, 1323-1340. [CrossRef]

151. Schreiber, V.; Dersch, J.; Puzik, K.; Backer, O.; Liu, X.; Stork, S.; Schulz, J.; Heimerl, T.; Klingl, A.; Zauner, S.; et al. The Central Vacuole of the Diatom Phaeodactylum tricornutum: Identification of New Vacuolar Membrane Proteins and of a Functional Di-leucine-based Targeting Motif. Protist 2017, 168, 271-282. [CrossRef]

152. Wei, C.; Zhou, X.; Zhang, Y. Improving intracellular production of recombinant protein in Pichia pastoris using an optimized preinduction glycerol-feeding scheme. Appl. Microbiol. Biotechnol. 2008, 78, 257-264. [CrossRef]

153. Zou, G.; Ochiai, H.; Huang, W.; Yang, Q.; Li, C.; Wang, L.-X. Chemoenzymatic Synthesis and Fc $\gamma$ Receptor Binding of Homogeneous Glycoforms of Antibody Fc Domain. Presence of a Bisecting Sugar Moiety Enhances the Affinity of Fc to Fc $\gamma$ IIIla Receptor. J. Am. Chem. Soc. 2011, 133, 18975-18991. [CrossRef]

154. Fabris, M.; Matthijs, M.; Carbonelle, S.; Moses, T.; Pollier, J.; Dasseville, R.; Baart, G.J.; Vyverman, W.; Goossens, A. Tracking the sterol biosynthesis pathway of the diatom Phaeodactylum tricornutum. New Phytol. 2014, 204, 521-535. [CrossRef]

155. Pollier, J.; Vancaester, E.; Kuzhiumparambil, U.; Vickers, C.E.; Vandepoele, K.; Goossens, A.; Fabris, M. A widespread alternative squalene epoxidase participates in eukaryote steroid biosynthesis. Nat. Microbiol 2019, 4, 226-233. [CrossRef]

156. Schuster, M.; Umana, P.; Ferrara, C.; Brunker, P.; Gerdes, C.; Waxenecker, G.; Wiederkum, S.; Schwager, C.; Loibner, H.; Himmler, G.; et al. Improved effector functions of a therapeutic monoclonal Lewis Y-specific antibody by glycoform engineering. Cancer Res. 2005, 65, 7934-7941. [CrossRef] [PubMed]

157. Cameron, F.; McCormack, P.L. Obinutuzumab: First Global Approval. Drugs 2014, 74, 147-154. [CrossRef] [PubMed]

158. Cheng, J.K.; Lewis, A.M.; Kim, D.S.; Dyess, T.; Alper, H.S. Identifying and retargeting transcriptional hot spots in the human genome. Biotechnol. J. 2016, 11, 1100-1109. [CrossRef] [PubMed]

159. Lee, J.S.; Kallehauge, T.B.; Pedersen, L.E.; Kildegaard, H.F. Site-specific integration in CHO cells mediated by CRISPR/Cas9 and homology-directed DNA repair pathway. Sci. Rep. 2015, 5, 8572. [CrossRef] [PubMed]

160. Papapetrou, E.P.; Schambach, A. Gene Insertion Into Genomic Safe Harbors for Human Gene Therapy. Mol. Therapy 2016, 24, 678-684. [CrossRef] [PubMed]

161. Clausen, H.; Wandall, H.H.; Steentoft, C.; Stanley, P.; Schnaar, R.L. Glycosylation engineering. In Essentials of Glycobiology [Internet], 3rd ed.; Cold Spring Harbor Laboratory Press: Cold Spring Harbor, NY, USA, 2017.

162. Omasa, T.; Tanaka, R.; Doi, T.; Ando, M.; Kitamoto, Y.; Honda, K.; Kishimoto, M.; Ohtake, H. Decrease in antithrombin III fucosylation by expressing GDP-fucose transporter siRNA in Chinese hamster ovary cells. J. Biosci. Bioeng. 2008, 106, 168-173. [CrossRef]

163. Myrbraten, I.S.; Wiull, K.; Salehian, Z.; Havarstein, L.S.; Straume, D.; Mathiesen, G.; Kjos, M. CRISPR Interference for Rapid Knockdown of Essential Cell Cycle Genes in Lactobacillus plantarum. mSphere 2019, 4. [CrossRef]

164. Cheng, X.; Liu, G.; Ke, W.; Zhao, L.; Lv, B.; Ma, X.; Xu, N.; Xia, X.; Deng, X.; Zheng, C.; et al. Building a multipurpose insertional mutant library for forward and reverse genetics in Chlamydomonas. Plant. Methods 2017, 13, 36. [CrossRef]

165. Schulze, S.; Oltmanns, A.; Machnik, N.; Liu, G.; Xu, N.; Jarmatz, N.; Scholz, M.; Sugimoto, K.; Fufezan, C.; Huang, K.; et al. N-Glycoproteomic Characterization of Mannosidase and Xylosyltransferase Mutant Strains of Chlamydomonasreinhardtii. Plant. Physiol. 2018, 176, 1952-1964. [CrossRef]

166. Pereira, N.A.; Chan, K.F.; Lin, P.C.; Song, Z. The "less-is-more" in therapeutic antibodies: Afucosylated anti-cancer antibodies with enhanced antibody-dependent cellular cytotoxicity. MAbs 2018, 10, 693-711. [CrossRef]

167. Bobrowicz, P.; Davidson, R.C.; Li, H.; Potgieter, T.I.; Nett, J.H.; Hamilton, S.R.; Stadheim, T.A.; Miele, R.G.; Bobrowicz, B.; Mitchell, T.; et al. Engineering of an artificial glycosylation pathway blocked in core oligosaccharide assembly in the yeast Pichia pastoris: Production of complex humanized glycoproteins with terminal galactose. Glycobiology 2004, 14, 757-766. [CrossRef] [PubMed] 
168. Cox, K.M.; Sterling, J.D.; Regan, J.T.; Gasdaska, J.R.; Frantz, K.K.; Peele, C.G.; Black, A.; Passmore, D.; Moldovan-Loomis, C.; Srinivasan, M.; et al. Glycan optimization of a human monoclonal antibody in the aquatic plant Lemna minor. Nat. Biotechnol. 2006, 24, 1591-1597. [CrossRef] [PubMed]

169. Strasser, R.; Altmann, F.; Mach, L.; Glössl, J.; Steinkellner, H. Generation of Arabidopsis thaliana plants with complex N-glycans lacking $\beta 1,2-$ linked xylose and core $\alpha 1$,3-linked fucose. Febs Lett. 2004, 561, 132-136. [CrossRef]

170. Strasser, R.; Stadlmann, J.; Schahs, M.; Stiegler, G.; Quendler, H.; Mach, L.; Glossl, J.; Weterings, K.; Pabst, M.; Steinkellner, H. Generation of glyco-engineered Nicotiana benthamiana for the production of monoclonal antibodies with a homogeneous human-like N-glycan structure. Plant. Biotechnol. J. 2008, 6, 392-402. [CrossRef]

171. Castilho, A.; Strasser, R.; Stadlmann, J.; Grass, J.; Jez, J.; Gattinger, P.; Kunert, R.; Quendler, H.; Pabst, M.; Leonard, R.; et al. In planta protein sialylation through overexpression of the respective mammalian pathway. J. Biol. Chem. 2010, 285, 15923-15930. [CrossRef]

172. Castilho, A.; Gattinger, P.; Grass, J.; Jez, J.; Pabst, M.; Altmann, F.; Gorfer, M.; Strasser, R.; Steinkellner, H. $\mathrm{N}$-glycosylation engineering of plants for the biosynthesis of glycoproteins with bisected and branched complex N-glycans. Glycobiology 2011, 21, 813-823. [CrossRef]

173. Weikert, S.; Papac, D.; Briggs, J.; Cowfer, D.; Tom, S.; Gawlitzek, M.; Lofgren, J.; Mehta, S.; Chisholm, V.; Modi, N.; et al. Engineering Chinese hamster ovary cells to maximize sialic acid content of recombinant glycoproteins. Nat. Biotechnol. 1999, 17, 1116-1121. [CrossRef]

174. Bork, K.; Reutter, W.; Weidemann, W.; Horstkorte, R. Enhanced sialylation of EPO by overexpression of UDP-GlcNAc 2-epimerase/ManAc kinase containing a sialuria mutation in CHO cells. Febs Lett. 2007, 581, 4195-4198. [CrossRef]

175. Goh, J.S.Y.; Liu, Y.; Liu, H.; Chan, K.F.; Wan, C.; Teo, G.; Zhou, X.; Xie, F.; Zhang, P.; Zhang, Y.; et al. Highly sialylated recombinant human erythropoietin production in large-scale perfusion bioreactor utilizing CHO-gmt4 (JW152) with restored GnT I function. Biotechnol. J. 2014, 9, 100-109. [CrossRef]

(C) 2020 by the authors. Licensee MDPI, Basel, Switzerland. This article is an open access article distributed under the terms and conditions of the Creative Commons Attribution (CC BY) license (http://creativecommons.org/licenses/by/4.0/). 